Ewa Matuszczyk

BIAŁOSTOCKIE

TEKI

HISTORYCZNE

TOM 16/2018

ISSN 1425-1930

Lelów

DOI: $10.15290 /$ bth.2018.16.01

\title{
Dlaczego wciąż warto czytać Platona, czyli o pieniądzu inaczej
}

\author{
Niektóre kręgi próby kierowania się zasadami \\ moralnymi, uważaja za naiwne lub głupie. \\ $\mathrm{O}$ tej formie idiotyzmu nie mam nic do powiedzenia. \\ N. Chomsky, Polityka. Anarchizm. Lingwistyka, \\ Poznań 2007, s. 230
}

\section{Co nam mówi Koniec historii Francisa Fukuyamy o metodologii ekonomicznego i politycznego dyskursu współczesności}

Sensowny dyskurs o sposobach i skutkach pomnażania pieniędzy oraz o sposobach i skutkach zarządzania nimi powinien zawierać w sobie etyczny ładunek ocenny, ponieważ nie jest niczym innym jak narracją o ludziach i dotyczącą ludzi. Dyskurs, który tego nie robi, stwarzając pozory aksjologicznej neutralności, z góry należy uznać za nieobiektywny, mający pełnić funkcje perswazyjne, czy wręcz apologetyczne. Warunkiem właściwej oceny heurystycznej dyskursu zawierającego oceny etyczne, jest zwrócenie uwagi na jego mniej lub bardziej ukryte założenia metodologiczne. Moim zdaniem, niepoprawne metodologicznie jest mówienie o ludziach zajmujących się pieniędzmi, które nie osadza go w bardzo szerokich kontekstach teoretycznych. Zaliczam do nich powiązane ściśle ze sobą dyskursy o:

- kapitalizmie, czyli ustroju społeczno-gospodarczym, którego pieniądz jest sednem;

- ekonomii jako nauce, która pod pozorem aksjologicznej neutralności częstokroć uzasadnia wszelkie nieetyczne posługiwanie się pieniądzem, uprawiając w tym celu żonglerkę słowami;

- metodologii tejże nauki, która wybiórczo czerpie z nauk społecznych i humanistycznych niektóre, „technokratyczne” wątki dotyczące rozumienia człowieka, twierdząc, że nic poza nimi nie mają one do zaoferowania;

- uwikłaniu nauki ekonomii w bieżącą politykę, inspirowaną i kierowaną przez ludzi wielkich korporacji, którzy uspołeczniają koszty i ryzyka prowadzenia własnej działalności, nie dzieląc się ze społeczeństwem swym zyskiem. 
Od razu trzeba podkreślić, że mało która monografia ekonomiczna spełnia te warunki, a podręczniki do ekonomii można posądzić o programowe wręcz ignorowanie metodologii, która zasadza się na wszechstronnym i krytycznym myśleniu o zjawiskach ekonomicznych. Obecnie nauka ekonomia głównego nurtu, zwłaszcza w Polsce po 1989 r., (mimo, że na uniwersyteckich wydziałach ekonomii studiuje się historię gospodarczą) uprawiana jest jako nauka ahistoryczna, traktująca przeszłość jak serię ekonomicznych pomyłek na drodze do stworzenia ustroju niesprzecznego wewnętrznie, racjonalnego i tym samym nieobalalnego. Jednym słowem, sposobem swojego funkcjonowania i głoszonymi tezami sugeruje ona bezalternatywność otaczającej nas rzeczywistości społeczno-gospodarczej i politycznej. Ten styl myślenia ucieleśnił w swojej książce Koniec historii w 1992 r. amerykański politolog, były zastępca dyrektora Zespołu Planowania Politycznego Departamentu Stanu USA, Francis Fukuyama, który oświadczył, że ,tylko liberalna demokracja nie jest obciążona fundamentalnymi wadami, sprzecznościami wewnętrznymi oraz niedostatkiem racjonalności, czyli tym, co wiodło dawne ustroje do nieuchronnego upadku"'. Warto dobrze zapamiętać zestaw użytych tu pojęć takich, jak brak fundamentalnych wad, brak sprzeczności wewnętrznych, pełna racjonalność, niemożność nieuchronnego upadku, ponieważ wszystkie są ocenne, a dokładniej, apologetyczne. Wszystkie znajdziemy również u Platona, o którym będzie mowa poniżej, tyle że u niego mają dosłownie odwrotny sens. Mianowicie, są nieocenne i opisowe. Opis zaś brzmi następująco: każdy ustrój jest zagrożony fundamentalnymi wadami i wewnętrznymi sprzecznościami z powodu nieusuwalnego niedostatku racjonalności większości jednostek, zwłaszcza parających się ekonomią i wojskowością, a zatem każdy ustrój nieuwzględniający tych wad (usunąć ich nie można) zagrożony jest nieuchronnym upadkiem.

Warty podkreślenia jest fakt, że do owego wstrząsającego wniosku o niemożliwości upadku kapitalizmu Autor doszedł jakoby, ,posługując się modelem nauk przyrodniczych”, dzięki czemu przedstawił „ekonomiczną interpretację zmiany historycznej”. Antycypując dalsze nasze analizy, chcę zwrócić uwagę, że wzmianka o metodzie, którą zastosował, nie tylko nie jest przypadkowa, lecz wręcz kluczowa $\mathrm{w}$ sensie poznawczym i propagandowym. Podkreślanie jej ma pozytywny wydźwięk propagandowy, a poznawczo jest ona fałszywa. W karierze naukowej Fukuyamy skondensowane są wszystkie wady i iluzje myślenia o społeczeństwie ludzi, którzy faktycznie społeczeństwem zarządzają. W niniejszym artykule chcę nie tylko je wymienić, ale także wskazać i przeanalizować ich przyczyny takie, jak łączenie roli naukowca i kapitalistycznego polityka, przypisywanie centralnego znaczenia tezom formułowanym przez specyficznie uprawiane nauki ekonomiczne, stawianie znaku równości między kapitalizmem i demokra-

\footnotetext{
1 F. Fukuyama, Koniec historii, Poznań 1996, s. 9.
} 
cją liberalną, przypisywanie cech liberalnej demokracji samemu kapitalizmowi, przekonanie o zasadniczo racjonalnej postawie polityków, ekonomistów-naukowców oraz ekonomistów-praktyków, przenoszenie modeli nauk przyrodniczych do nauk społecznych, by pod pozorem ich unaukowienia skuteczniej budować i propagować pozbawione jakoby alternatyw narracje społeczne.

Fukuyama jako wysoki funkcjonariusz Zespołu Planowania Politycznego Departamentu Stanu USA (sama nazwa tego zespołu budzi podejrzenia o manipulacyjny stosunek do rzeczywistości) jest jednak bardzo nieroztropny, przyznając wprost, że współczesny system kapitalistyczny nie jest wynikiem naturalnego rozwoju społecznego, ale jest dziełem ludzkiego myślenia i ludzkich decyzji w takim samym stopniu, $\mathrm{w}$ jakim jest, nienaturalny niby, system komunistyczny. „Współczesne demokracje liberalne - pisze on - nie wypłynęły z mglistych oparów tradycji. Podobnie jak społeczeństwa komunistyczne, zostały świadomie skonstruowane przez ludzi w określonym momencie czasowym na podłożu pewnego teoretycznego rozumienia człowieka i instytucji politycznych, które powinny kierować społeczeństwem ludzkim"2 (wszystkie podkreślenia moje - E. M.). Słowa: „świadoma konstrukcja” oraz „teoria człowieka i instytucji politycznych" dowodzą, że mamy tu do czynienia z wyborem i wiedzą. Skoro kapitalistyczna rzeczywistość, zwana dla niepoznaki demokracją liberalną, została skonstruowana na podstawie pewnej teorii człowieka i instytucji politycznych, to pytanie, jaka jest wartość tej teorii, dlaczego wybrano za podstawę działań tę, a nie raczej inną teorię? - jest jak najbardziej zasadne.

Dla porządku należy dodać, iż powszechna krytyka, z którą spotkała się książka Fukuyamy, zmuszająca go do odwołania tezy o końcu historii, nie zmieniła jednak w żadnym stopniu niewyrażanych przez niego expressis verbis założeń dyskursu o kapitalizmie, toczonego bezustannie przez ekonomistów, polityków i media głównego nurtu, dzięki czemu zdołał zdominować świadomość społeczną. Dyskursu, który faktycznie podtrzymuje wszystkie wyłożone przez Fukuyamę tezy. Jego dominująca rola wymaga, by przyjrzeć się bliżej procesowi budowania tej dominacji.

\section{Co to jest pieniądz według współczesnej ekonomii? Rozważań metodologicznych ciąg dalszy}

Mówi się: „pieniądz rządzi światem”. Dla filologa, socjologa, czy filozofa kluczowe jest tu sformułowanie „mówi się”, ponieważ każda z tych dziedzin jest świadoma tego, że mówienie ma kolosalny wpływ na myślenie. W przytoczonym sformułowaniu bezosobowy tryb: „mówi się”, nie jest neutralny, lecz

2 Ibidem, s. 224. 
nadaje głoszonym tezom pozory obiektywności, a fakt, że jest to sformułowanie zakorzenione $\mathrm{w}$ języku potocznym, nadaje mu pozór odwiecznej mądrości, skondensowanego, wielowiekowego doświadczenia mnóstwa pokoleń. Ekonomia jako nauka pomija owo „mówi się”, koncentrując się na tezie następującej po nim i brzmiącej - „pieniądz rządzi światem”. Nie ludzie, broń Boże, ale właśnie pieniądz. Przyjrzyjmy się więc pierwszej z brzegu encyklopedycznej definicji pieniądza w celu zbadania, w którym to miejscu następuje hipostazowanie kategorii ekonomicznych, pozwalające politykom sugerować, że na ekonomiczne życie społeczeństw mają oni ograniczony wpływ, bo rządzi się ono własnymi, nieubłaganymi prawami. Z najbardziej popularnej encyklopedii o pieniądzu dowiadujemy się, że jest to ,ogólny, powszechnie stosowany ekwiwalent trwale wyrażający wartość wszystkich towarów i usług, bezpośrednio na nie wymienialny”, a zarazem tego, że „zarówno rozmiary obiegu pieniądza bankowego, jak i gotówkowego są ściśle regulowane; odbywa się to za pośrednictwem banku centralnego (w Polsce jest nim NBP), używającego rozmaitych instrumentów polityki pieniężnej (ustalenie stosunku pomiędzy wielkością wkładów bankowych a wielkością rezerw kasowych, regulowanie wysokości stopy procentowej, stosowanie działań walutowych w ramach tzw. $\rightarrow$ operacji otwartego rynku”’.

Jak widać, encyklopedyczna definicja pieniądza nigdzie nie napomyka nawet o człowieku, nie sposób więc dociec, co za teoretyczna wizja człowieka stoi za pieniądzem. Nie hipostazuje go i nie mistyfikuje go jednak całkowicie, albowiem nie sugeruje jego samodzielności i samowystarczalności, lecz wyraźnie wskazuje na banki i rynek, jako na instytucje wywierające na niego wpływ przez świadome regulacje. Może więc hipostaza i mistyfikacja tego pojęcia, nadawanie pieniądzu pozoru samodzielnego funkcjonowania, jest pochodną mistyfikacji pojęć „banki” i „rynek”? Żeby to sprawdzić, przejdźmy w takim razie do analizy definicji banków i rynku. O bankach czytamy więc, że są to „przedsiębiorstwa, których przedmiotem działania są operacje pieniężne o charakterze biernym, czynnym lub usługowym”, rynek zaś, według tego samego źródła, to „miejsce konfrontacji popytu i podaży dóbr i usług oraz cen, dochodów i kapitałów"s.

Zauważmy, że również w tych definicjach konsekwentnie nie używa się pojęcia „człowiek”, aczkolwiek nie ma wątpliwości, że pieniędzy używają ludzie, w bankach decyzje podejmują również ludzie, popyt oznacza zapotrzebowanie ludzi na dobra i usługi, podaż zaś - oferowane przez innych ludzi dobra i usługi, w związku z tym na rynku dochodzi do konfrontacji ludzi. Skoro zaś za pieniędzmi, bankami i rynkami stoją ludzie, to, naszym zdaniem, ekonomia nie powinna obywać się bez rzetelnej i pogłębionej wiedzy socjologicznej, psycho-

\footnotetext{
3 Popularna Encyklopedia Powszechna, Kraków 2003, t. 14, s. 214.

4 Ibidem, t. 2, s. 43.

5 Ibidem, t. 17, s. 11.
} 
logicznej i historycznej na ich temat. W dodatku, ta pewna teoretyczna wizja człowieka, o której wspominał cytowany wyżej naukowiec-polityk Francis Fukuyama, będąca sednem ustroju kapitalistycznego, powinna być przez ekonomię wyrażona expressis verbis. $\mathrm{Z}$ przytoczonych definicji wynika, że nie jest.

Zabieg, polegający na zaniedbaniu pewnych okoliczności badanego zjawiska (w tym przypadku człowieka) w celu przyjrzenia mu się w stanie czystym jest, oczywiście, metodologicznie uzasadniony i płodny. Znany jest on pod nazwą eksperymentu myślowego i stosowany od dawna w fizyce. Wszyscy wiemy, np., że ciało wprawione w ruch porusza się ruchem jednostajnym, ale przecież nie jest to wiedza wynikająca $\mathrm{z}$ obserwacji. W warunkach, które nas otaczają żadne ciało tak się nie porusza. Wszystkie wprawione w ruch ciała prędzej, czy później spowalniają i zatrzymują się. Skąd więc dowiedzieliśmy się, że porusza się ono ruchem jednostajnym? No cóż, wystarczyło tylko abstrahować od obserwowanej rzeczywistości i zadać sobie pytanie (to „tylko” zajęło nam ponad 2000 lat), jak poruszałyby się wprawione w ruch ciała, gdyby istniały wyłącznie one i próżnia. Logiczna odpowiedź była jedna: poruszałyby się ruchem jednostajnym, albowiem w próżni z definicji nie ma niczego, co by je spowalniało i zatrzymywało. Od tego stwierdzenia, opisującego modelowe zachowanie się ciał, można przejść z powrotem do otaczającej nas rzeczywistości, w której wszystkie ciała spowalniają i zatrzymują się, i zadać sobie pytanie, które z ogromnej liczby elementów, składających się na tę rzeczywistość powodują, że zachowują się one inaczej, niż w próżni.

Kiedy więc widzimy, jak nauka ekonomii opisuje zjawiska gospodarcze, zaniedbując wiedzę o tym, jaki wpływ na nie ma uczestnictwo w nich pełnokrwistych ludzi, nie musi to od razu budzić naszych obaw. Rozbrat nauki i praktyki ekonomii z socjologią, psychologią, historią nie musi być dla niej groźny, o ile jest chwilowym metodologicznym zabiegiem, zastosowanym po to, by zbudować model, który posłuży nam do lepszego zrozumienia rzeczywistości. Gorzej, gdy raz zaniedbana wiedza socjologiczna, psychologiczna i historyczna nie pojawia się w ekonomii wcale, sugerując, że procesy ekonomiczne są tak niezależne od ludzkich uczuć i woli, jak procesy fizyczne (np. ruch planet w Układzie Słonecznym), chemiczne i temu podobne, a tzw. człowiek ekonomiczny jest ucieleśnieniem racjonalności. Niestety, właśnie z taką sytuacją mamy w ekonomii do czynienia.

Metodologicznym punktem wyjścia naszych rozważań jest podzielane z Josephem Voglem przekonanie, że „,kapitalizmu nie można zdefiniować bez kapitalistów i praktyki kapitalistycznej”'. Ponieważ zaś każda działalność jest oparta na jakiejś teorii rzeczywistości, to na początek warto się przyjrzeć, jakie to wyobrażenia, świadome bądź nieświadome, napędzają ich aktywność. W tym celu

6 J. Vogel, Widmo kapitatu, Warszawa 2015, s. 143. 
konieczna i wystarczająca jest analiza tekstów ekonomicznych i publicystycznych oraz społecznych zachowań praktyków ekonomii. Znajdziemy ją w pracach Naomi Klein, Noama Chomsky'ego, Josepha Stiglitza, Paula Krugmana ${ }^{7}$, Immanuela Wallersteina ${ }^{8}$, Davida Osta, Elizabeth Dunn, a także polskich badaczy Krzysztofa Krzysztofka, Marka S. Szczepańskiego, czy Andrzeja Ziemilskiego i wielu innych. Analiza ta dowodzi, że owe teksty sugerują, iż nauka zwana ekonomią oraz ekonomiści-praktycy o ludziach domniemują, co następuje:

a) ludzie zasadniczo nie są równi; zarządzający sprawami ekonomicznymi cechują się nadzwyczajną racjonalnością i tylko nią, a nie jakimiś uczuciami w rodzaju niepohamowanej chęci zysku, czy innych namiętności; natomiast klienci sklepów, banków, a także inni indywidualni odbiorcy wszelkich usług, oferowanych przez zarządzających gospodarką, są bezrozumnymi, nieracjonalnymi obiektami, podlegającymi manipulacji przez reklamy, PR oraz wszelkiego innego typu marketingowe i socjotechniczne chwyty;

b) pomiędzy tymi dwoma zasadniczymi grupami plączą się, zawdzięczający wszystko kapitalistom/pracodawcom pracobiorcy, których jedynym marzeniem jest zapomnieć o statusie pracobiorcy i stać się przede wszystkim zasobnymi klientami, choćby miało się to odbyć kosztem zaciągnięcia kredytu w Wonga.com na ponad $390 \%$ w skali roku'; mogą oni również, jak twierdzą politycy i mass media głównego nurtu, przejść w szeregi klasy zarządców gospodarką poprzez... samozatrudnienie;

c) nie istnieją klasy, warstwy, czy inne trwałe, dziedziczone podziały społeczne, jak w czasach niewolnictwa, czy pańszczyzny; wszyscy jesteśmy równi i wyposażeni w podobne szanse życiowe;

d) teza c) nie stoi w sprzeczności tezą a), ponieważ nierówności, o których mowa w tezie a) nie są dziedziczone; obie tezy w zależności od okoliczności odgrywają różną rolę: teza pierwsza jest wyraźnie opisowa (wszyscy zgodzimy się co do tego, że nie jesteśmy równi, nawet jeśli nie zgodzimy się co do tego, na czym ta nierówność polega), teza trzecia zaś jest propagandowa i perswazyjna zarazem, albowiem jej ukrytym celem jest zduszenie w zarodku ewentualnych roszczeń tych, co są niezadowoleni ze swej pozycji społecznej, sugerując, iż w społeczeństwie kapitalistycznym wszyscy posiadają możliwość nieograniczonej wertykalnej mobilności społecznej;

\footnotetext{
7 Zarówno J. Stiglitz, jak i P. Krugman należą do tzw. ekonomistów „heterodoksyjnych”. Obaj są laureatami Nagrody Nobla, pierwszy - z roku 2001, drugi - z 2008.

8 Jako ciekawostkę warto podkreślić polskie koligacje teoretyczne I. Wallersteina, który wprost odwołuje się do polskiej tradycji socjologii historycznej, szczególnie zaś do prac Mariana Małowista. Zob. A. W. Nowak, Przedmowa, [w:] I. Wallerstein, Utopistyka. Alternatywy historyczne dla XXI wieku, Poznań 2008, s. 6.

9 Informacja pochodzi z reklam tej firmy, pojawiających się regularnie w telewizjach w Polsce w sierpniu 2018 r. Pytanie, kiedy w Polsce, według rządzących, zaczyna się lichwa, jest w tej sytuacji bardzo aktualne.
} 
e) pogoń za zyskiem, zwana maksymalizacją zysku, jest celem racjonalnym; racjonalne jest też wszystko, co służy osiągnięciu tego celu;

f) wolnorynkowa działalność gospodarcza zasadniczo jest neutralna aksjologicznie, ale nie zmienia to faktu, że sama w sobie jest dobra; dopuszcza się tu sprzeczne twierdzenia, z których jedno wyklucza krytyczną dyskusję o działalności gospodarczej i ocenianie jej w kategoriach „dobra” - „zła”, zaś drugie ocenia ją jako bezwarunkowo dobrą i ją gloryfikuje.

Przyjrzenie się wszystkim tym mniej lub bardziej ukrytym założeniom myśli i praktyki ekonomicznej daje nam w sumie wyobrażenie o prostactwie socjologii oraz psychologii społecznej i indywidualnej, leżącej u podstaw nauki i praktyki ekonomicznej głównego nurtu. Podobnie uproszczona psychologia i socjologia przenika również dyskurs polityczny, publicystyczny i świadomość społeczną, co nie może dziwić skoro dobro korporacji mają one na względzie. Nawet partie mieniące się lewicowymi, o ile należą do głównego nurtu polityki, nie ważą się wprowadzać w obieg innych tez na temat życia gospodarczego i społecznego, niż przytoczone wyżej. Ukryły się zresztą pod nazwą „,nowej lewicy”, kulturowej, żeby nie zostać wyrzuconymi poza politykę głównego nurtu, jak to uczyniono ze „starą lewicą”, ekonomiczną.

Zdecydowana większość dorobku filozofii społecznej, socjologii, psychologii i historii, a także nauk im pokrewnych pozostaje niewykorzystana, albowiem z istotnych powodów merytorycznych nie daje się zaprząc do realizacji bieżących celów ekonomistów-naukowców i ekonomistów-praktyków. Jest więc ignorowana nie tylko przez nich, ale też przez „,czwartą władzę”, która wręcz uważa się za powołaną do głoszenia bezzasadności wszelkich teoretycznych dyskusji na temat wymienionych wyżej podstaw współczesnego świata społeczno-gospodarczego.

Warto zadać sobie pytanie, kiedy doszło do rozbicia świata i badającej go nauki na nieprzystające fragmenty oraz co było powodem tego wydarzenia. Immanuel Wallerstein trafnie wskazuje zarówno jego czas, jak i przyczynę. Stało się to dopiero w XIX i XX w., wraz z nastaniem panowania kapitalizmu. Wówczas to naukowcy zaczęli opierać „,swoje roszczenia do społecznego poparcia i prestiżu przede wszystkim na jednym fakcie. Mianowicie byli oni zdolni tworzyć wiedzę dającą się przełożyć na ulepszenia technologiczne - co spotkało się ze sporym uznaniem ze strony panujących (podkreślenia moje - E. M.). Tak więc naukowcy mieli wszelkie materialne i społeczne przesłanki, by wypromować i przeprowadzić tak zwany rozwód między nauką a filozofią" ${ }^{10}$. Podkreślmy raz jeszcze, to nie odkrycie jakiejś nowej wiedzy, prawdy, ale zdolność dostarczania ulepszeń technologicznych oraz poparcie władzy dla tej działalności są tymi dwoma elementami, które przeorały funkcjonowanie nauk społecznych i humani-

10 I. Wallerstein, Europejski uniwersalizm. Retoryka władzy, Warszawa 2007, s. 76. 
stycznych. Stanęły one do wyścigu z naukami przyrodniczymi o społeczny prestiż i materialne podstawy swego bytu (dzisiaj materialna podstawa bytu tych nauk opiera się na systemie grantów). W celu wykazania się praktyczną użytecznością stały się one dostarczycielkami wszelkiego rodzaju wiedzy o możliwościach manipulowania ludźmi i wywierania na nich wpływu. Wiedza tego rodzaju cieszy się dzisiaj ogromnym wzięciem, zwłaszcza w krajach demokratycznych. Tworząc i propagując ją nauki społeczne i humanistyczne dołączyły tym samym do chóru nauk, które pojęciu ,praktyczny” odebrały, jak się zdaje bezpowrotnie, jego pierwotny sens i skojarzyły go nie z prawdziwością i moralnością, ale wyłącznie z użytecznością i skutecznością. Skuteczność, czy to w skonstruowaniu żarówki, czy w budowie bomby atomowej, czy manipulowaniu ludźmi uznano za wartości w jednakowym stopniu pozytywne i niepodlegające dyskusji.

Oderwanie się nauki od filozofii par excellence, czyli rozpatrującej problemy również z etycznego i antropologicznego punktu widzenia, przybrało postać jednostronnej dyskusji epistemologicznej, której nadano pozór dyskusji głęboko naukowej. W jej trakcie wychodzono ze słusznych skądinąd przesłanek. Twierdzono, mianowicie, że przedmiot nauk przyrodniczych oraz przedmiot nauk społecznych i humanistycznych są różne i wymagają różnych metod, ale dołączono do niej fałszywą przesłankę, że metody nauk nieprzyrodniczych są gorsze. Uczeni humaniści ,podkreślali znaczenie analitycznego wglądu, hermeneutycznej wrażliwości lub empatycznego rozumienia (Verstehen) jako dróg prowadzących do prawdy. Twierdzili, że ten rodzaj prawdy jest dużo głębszy i nie mniej uniwersalny niż prawda tworzonych przez naukowców uogólnień, (...) kładli nacisk na centralne znaczenie wartości, dobra i piękna" ${ }^{11}$, ale przegrali. Przegrana nie była jednak spowodowana, jak sugerowano, wynikami dyskusji epistemologicznej, ale zastosowaniem do oceny jej wyników wąsko pojmowanej zasady użyteczności nauk. Usuwając pewne metody badań, jako nieprowadzące do użytecznych wniosków, usunięto wraz z nimi całą tematykę badań. Z obszaru nauki i praktycznej działalności człowieka zniknęła nie tylko etyka, czyli rozważania o moralności celów i środków do nich prowadzących, ale także zagadnienie alienacji, które w kontekście rozważań o pieniądzu ma bardzo doniosłe znaczenie. Koncepcja alienacji tłumaczy bowiem zmistyfikowany sposób funkcjonowania wytworów człowieka, w tym także pieniądza, zarówno jako kategorii ekonomicznej, jak i realnej rzeczy.

Podsumujmy: zarysowaliśmy pokrótce istniejący stan rzeczy w praktyce i nauce ekonomicznej, na który składają się:

- zmistyfikowane, zhipostazowane użycie kategorii ekonomicznych takich, jak pieniądz, banki, rynki, sugerujące, że nie stoją za nimi konkretni ludzie, realizujący przez nie swoje subiektywne cele i interesy;

11 Ibidem, s. 77. 
- opieranie się w praktyce i nauce ekonomii na niepełnej, zwulgaryzowanej wiedzy socjologicznej, psychologicznej i historycznej oraz propagowanie jej poprzez podręczniki, sprzedawane masowo poradniki oraz mass media głównego nurtu;

- oderwanie pojęcia „praktyczny” od jego wielowiekowego utożsamienia z moralnością i nadanie mu czysto utylitarnego, pozaetycznego sensu;

- zdyskredytowanie nauk społecznych i humanistycznych oraz ich metod, o ile nie pozują one na nauki quasi-przyrodnicze i nie wykazują się praktyczną użytecznością i skutecznością.

\section{Platońska socjologia opisowa, czyli jak bardzo jesteśmy podobni do Greków?}

Przedstawione wyżej tezy pokazują, że w myśleniu o społecznej roli kapitalistów, podlegamy zmasowanej, zorganizowanej presji. Powstaje pytanie, jak można się ,wymknąć temu ukrytemu naciskowi, który jest cały czas wywierany w trakcie czytania gazet, oglądania telewizji, czy lektury prac naukowych" 12 ? Podzielam metodologiczny postulat Pierrea Bourdieu, wybitnego francuskiego socjologa, że ,jednym z najpotężniejszych środków ułatwiających wyrwanie się jest społeczna historia problemów, tematów i narzędzi myślenia"13. Poświęcenie uwagi analizie poglądów Platona na „kapitalistyczne” elementy społeczeństwa starożytnej Grecji stanowi próbę realizacji tego postulatu. Powinna ona ułatwić świeże spojrzenie, odmienne od oficjalnego, na żywotne zagadnienia współczesnych kapitalistycznych społeczeństw, w których ludzie pieniądza i reprezentowane przez nich wartości odgrywają dominującą rolę.

Przedstawiony w punkcie pierwszym i drugim mojego artykułu długi wstęp, rzucający światło na współczesną metodologię uprawiania nauk, w tym zwłaszcza ekonomii oraz traktowania kategorii ekonomicznych, miał na celu umożliwienie Czytelnikowi porównywania jej niejako na bieżąco z metodologią uprawiania nauk przez Platona, o czym będzie mowa poniżej. Chodziło mi o stworzenie konfiguracji luster, w której przeszłość teorii ogląda się w jej przyszłości, i na odwrót.

Mimo iż Platon, jak wiadomo, nie dysponował tak szczegółową wiedzą humanistyczną i społeczną, jaką posiadamy dzisiaj, nie znaczy to jednak, że nie posiadał jej wcale. Był wybitnym myślicielem, a zarazem bystrym obserwatorem i krytykiem społeczeństwa ówczesnego, którego wady inspirowały go do poszukiwań odpowiedzi, jak powinno ono funkcjonować. Wbrew pozorom zaś społe-

12 P. Bourdieu, Zaproszenie do socjologii refleksyjnej, Warszawa 2001, s. 237.

13 Ibidem, s. 237. 
czeństwo, w którym żył, pod wieloma względami niewiele różniło się od społeczeństwa nam współczesnego. Pomijając niebotyczną różnicę technologiczną, dzielącą społeczeństwo ówczesne i obecne, charakterystyczne wady społeczeństwa starożytnych Aten trafnie opisują współczesność. Mit o jakiejś wyjątkowości społeczeństw XX i XXI w. w świetle tego, co zamierzamy przedstawić, musi upaść.

Metodologicznym punktem wyjścia naszych rozważań jest teza, przyświecająca twórczości wybitnego niemieckiego socjologa Maxa Webera oraz francuskiego metodologa historii Fernanda Braudela ${ }^{14}$, głosząca, iż wszystkie podstawowe elementy kapitalizmu znane są ludzkości od dawna. Są nimi pieniądze, miasta i wymiana rynkowa. Dopiero jednak w XIX w. stały się one dominujące, wpływając na politykę i stanowienie prawa. Skoro zaś znane są od dawna, to warto prześledzić, co Platon miał do powiedzenia o ludziach zajmujących się pomnażaniem pieniędzy, oraz jak traktowano ich w ciągu całej historii do wieku XIX, jakie widziano dla nich miejsce w funkcjonowaniu państw i społeczeństw, i co spowodowało, że obecnie kapitalizm jest tak dominujący?

Platon nie napisał zwartego tekstu poświęconego, czy to metodologii, czy innym szczegółowym zagadnieniom - socjologicznym, etycznym, czy ontologicznym. Wszystkie założenia metodologiczne, wyłuszczone w niniejszym tekście, musiały więc zostać wyabstrahowane z jego dialogów. W języku dzisiejszych nauk społecznych jego szczegółowe zainteresowania można określić jako socjologię opisową i normatywną. Jej metodologiczną podstawą była wyrażona expressis verbis koncepcja etyki, którą po analizie jego tekstów można zrozumieć jako koncepcję trzech połączonych ze sobą kwestii: 1) co ludzi czynią, 2) co czynić mogą i 3) co czynić powinni. Taką właśnie strukturę, po wnikliwym zbadaniu, można nadać dialogowi Państwo, któremu z racji interesującej nas tutaj problematyki, poświęcimy najwięcej uwagi.

Już w pierwszej księdze Państwa Platona, która rozpoczyna się od wiele mówiącej dyskusji z zakresu etyki, wprowadzając nas bezpośrednio w krąg zagadnień natury politologicznej, socjologicznej, teologicznej i psychologicznej, wyjściowe pytanie: „do jakiego użytku albo do osiągania czego podczas pokoju" 15 służy sprawiedliwość - łączy rozważania o wartości (sprawiedliwość) z użytecznością. Takie postawienie sprawy przypomina od razu nie tylko założenia filozoficznego utylitaryzmu przełomu XVIII i XIX w., charakterystycznego dla rozkwitającego kapitalizmu, ale także całą, nieświadomą swych filozoficznych korzeni, współczesną praktykę społecznego myślenia. Również pierwsza z padających tam hipotetycznych odpowiedzi brzmi współcześnie, niemal „kapitalistycznie", gdyż twierdzi się w niej, że sprawiedliwość niezbędna jest do

\footnotetext{
14 F. Braudel, Dynamika kapitalizmu, Warszawa 2013, s. 22-27.

15 Platon, Państwo, Kęty 1997, s. 20-21.
} 
interesów, przez które rozumie się spółki pieniężne ${ }^{16}$. W toku dalszej dyskusji odpowiedź ta nie utrzymuje się. Co najważniejsze, upada nie pod ciężarem argumentów natury teoretycznej (etycznej), ale argumentów natury empirycznej, czyli stanowiących opis pewnej praktyki życia politycznego i gospodarczego Grecji. Na nie powołuje się Trazymach, jeden z interlokutorów Platona/Sokratesa w analizowanym dialogu, którego można uznać za prekursora myślenia quasi-kapitalistycznego, szeroko rozpowszechnionego w ówczesnej Grecji. Odrzuca on zachowania etyczne za argument podając niemożność wykazania pozytywnego związku między sprawiedliwością a użytecznością $w$ różnych dziedzinach ludzkiej działalności. Twierdzi on, że „człowiek sprawiedliwy wszędzie ma mniej niż niesprawiedliwy. Najpierw w interesach, w spółkach. Gdziekolwiek się taki jeden z drugim zwiąże, to przy rozwiązaniu spółki nigdy nie znajdziesz, żeby sprawiedliwy miał z niej więcej niż niesprawiedliwy.

A następnie w stosunku do państwa, kiedy chodzi o podatki, to z jednakich sprawiedliwy wpłaca więcej, a niesprawiedliwy mniej. A jak można coś dostać, to ten nie dostaje nic, a tamten zyskuje grubo. A znowu jak jakiś urząd publiczny spełnia jeden i drugi, to dla sprawiedliwego jest kara - jeżeli już nie inna, to ta, że jego własne gospodarstwo schodzi przy tym na psy, bo on nie ma czasu dbać o nie, a z publicznego grosza takiemu nic nie przyjdzie, bo on jest sprawiedliwy, a oprócz tego jeszcze zaczynają go nienawidzić krewni i znajomi, kiedy im nie chce oddawać żadnych przysług wbrew sprawiedliwości. (...)" Konkluzja Trazymacha jest jednoznaczna, a mianowicie, „lepiej człowiek wychodzi w swoich prywatnych sprawach na niesprawiedliwości niż na sprawiedliwości" ${ }^{17}$. Krótko mówiąc, obserwacja ateńskiego życia publicznego dowodzi, że kierowanie się moralnością nie pomagało ówcześnie ani w robieniu interesów, ani w stosunkach z poborcami podatków, ani w pozyskiwaniu świadczeń ze strony państwa, ani w sprawowaniu funkcji publicznych. Nie zyskiwało się również dzięki temu uznania w oczach przyjaciół, czy krewnych, ponieważ ludzie cenili tylko tych, którzy przez sprawowanie urzędów mogli przysporzyć im jakichś dóbr, czyli akceptowali nepotyzm i kumoterstwo.

Wszystko to sprawiało, że szerokie koła obywateli Aten, jak zapisano dalej w tekście Państwa, ,sprawiedliwość zaliczają do rodzaju trudów i przykrości, które warto praktykować dla zarobków i dla opinii, dla dobrej sławy, ale sama dla siebie ta rzecz jest przykra, więc trzeba jej unikać"18. Właściwie, uściśla Trazymach, według powszechnej opinii wręcz ,nie trzeba chcieć być sprawiedliwym, ale chcieć takim wydawać się". Na pytanie, dlaczego wydawanie się uczciwym,

\footnotetext{
16 Ibidem, s. 21.

17 Ibidem, s. 35.

18 Ibidem, s. 50
} 
jest ważniejsze od bycia nim? pada odpowiedź, że „jeśli będę uczciwy, ale sobie $\mathrm{w}$ dodatku nie wyrobię opinii, to nic mi z tego nie przyjdzie, (...), tylko trudy i kary oczywiste. A jeśli będę nieuczciwy, a wyrobię sobie opinię nieskazitelną, to mi święte życie przepowiadają" ${ }^{19}$. Przytoczony cytat dowodzi więc, że już wówczas ceniono przede wszystkim dobrą opinię, wyrabianiem której zajmują się dzisiaj wyspecjalizowane agencje, wiedząc skądinąd, że często jest ona niezasłużona i nie odpowiada rzeczywistej wartości człowieka. Chodziło zawsze jednak o to, żeby „zrobić sobie fasadę, przybrać postawę, otoczyć się od frontu dekoracjami dzielności”"20. Użyte przez Platona pojęcia „fasada”, „dekoracja” brzmią w tym kontekście bardzo nowocześnie i są zupełnie jak wzięte z pracy Goffmana Człowiek $w$ teatrze życia codziennego. Konstatują szeroko znaną praktykę, polegającą na łączeniu ról społecznych z określonymi rzeczowymi artefaktami.

W analizowanym tekście Platon nie poprzestaje na sarkastycznym odtworzeniu „wielkości” celów życia swoich współziomków. Równie ironicznie pisze o środkach, jakie zalecają i stosują oni do ich osiągnięcia: „Ale oto powiada ktoś: nie jest łatwo maskować swój podły charakter. Trudno, powiemy - łatwe nie jest nic z rzeczy wielkich. (...) Żeby się zamaskować, wejdziemy w tajne związki i zawiążemy towarzystwa - a istnieją nauczyciele wymowy i udzielają mądrości potrzebnych na zgromadzeniach ludowych i w sądzie - więc jedno zyskamy wymową, a drugie gwałtem, tak żeby zawsze być górą, a kary uniknąć" 21 . Tak więc tajne stowarzyszenia, manipulacja zgromadzeniami i sądami przez mowę, a do tego jawna przemoc - oto zestaw środków używanych wówczas, opisywanych w XVIII w. przez Adama Smitha ${ }^{22}$ i znanych także współcześnie. Poświęcimy im więcej uwagi, zwłaszcza mowie, trochę później.

Skoncentrujmy się na razie na celach, które stawiał sobie w życiu przeciętny, wolny obywatel Aten. Każde z tych określeń, to znaczy zarówno „przeciętny”, jak i „wolny obywatel” ma dla nas istotne znaczenie, bo można je przypisać niemal każdemu współczesnemu Europejczykowi i porównać, do czego konkretnie przeciętnemu, wolnemu obywatelowi Aten potrzebne było budowanie fasady i tworzenie pozorów, i czy aby nasze potrzeby nie są identyczne?

Co za dobra więc spodziewał się osiągnąć starożytny Grek, o ile miał system wartości podobny do Trazymacha, dzięki odpowiedniej opinii? Ano pożytków z wydawania się sprawiedliwym wymienia się całe mnóstwo i wszystkie one, jako żywo, dla większości ludzi pozostają atrakcyjne również dzisiaj, poczynając od

\footnotetext{
19 Ibidem, s. 57.

20 Ibidem, s. 57.

21 Ibidem, s. 57-58.

22 Adam Smith pisze, iż ludzie interesu, kiedy dochodzi między nimi do rozmów, „to kończą się one na spiskach przeciwko społeczeństwu lub, w niektórych przypadkach, zmowie cenowej”. A. Smith, Badania nad natura i przyczynami bogactwa narodów, t. 1, Warszawa 1954, s. 169.
} 
objęcia władzy w państwie, przez sukcesy w sporcie, po możliwość korzystnego ożenku. Twierdzi więc Trazymach, że robiono to wszystko ,żeby władzę objąć w państwie, budując na opinii swej nieskazitelności, a potem żonę wziąć, skąd by mu się podobało, i córki wydawać, za kogo by chciał, i wiązać się, i żyć z kim by chciał, a oprócz tego zarabiać grubo, nie martwiąc się tym, że zysk nieuczciwy. Taki pojedzie na igrzyska i zwycięży, i jako człowiek prywatny, i jako przedstawiciel państwa, i będzie miał więcej niż jego przeciwnicy, a jak będzie miał więcej, to zrobi majątek i przyjaciołom będzie świadczył dobrodziejstwa, a nieprzyjaciołom szkodził, a bogom ofiary i wota będzie składał jak się należy z wielką pompą i będzie bogom służył znacznie lepiej niż człowiek sprawiedliwy, i będzie dbał o tych ludzi, o których zechce"23.

Po wysłuchaniu Trazymacha Platon zwraca przede wszystkim na ten wątek jego wypowiedzi, w którym mówi on, skąd ludzie czerpią przyzwolenie na podobnego rodzaju nieetyczne zachowania, albo przynajmniej udają, że stamtąd czerpią. Nie zadowala go przekonanie Trazymacha, że skoro tak myślą i robią wszyscy, to dyskusja na ten temat jest skończona. Wręcz przeciwnie, dla niego jest to powód do rozważań na temat pochodzenia ludzkich przekonań. Żeby wyjaśnić to zagadnienie, postępuje jak rasowy socjolog wiedzy, szukający społecznych źródeł ludzkich przekonań. Analizuje on w związku z tym, na podstawie jakich przesłanek Trazymach powziął przekonanie, o słuszności swych wyobrażeń o bogach? Może jednak bogowie sprzyjają sprawiedliwym i karzą niesprawiedliwych, nie dając im się przekupić wotami i modlitwami? Może w greckiej mitologii da się wyodrębnić zestaw zasad moralnych, potępiających interesowne zachowania społeczne? Niestety, dokonana przez Platona analiza tekstów Homera, czy Hezjoda, poetów najbardziej poważanych przez starożytnych Greków, czyli potoczną opinię, potwierdza przekonania Trazymacha, że nie trzeba być sprawiedliwym, żeby zyskać przychylność bogów. Homer wielokrotnie bowiem podkreśla, że:

„Wpływać nawet na bogów

Można; są na to ofiary i modły są na to błagalne,

Kropi się na to i kadzi - tak ludzie boskie wyroki

Zmieniać umieją, gdy który przeskrobie coś albo nagrzeszy"24.

Platon zwraca również uwagę nie tylko na sprzyjającą nieprawościom wiarę w możliwość przekupienia bogów, ale na patologiczny wręcz użytek, jaki niektórzy jego współcześni czynią z tego przekonania. Otóż, nieuchronnie prowadzi ono do powstania w społeczeństwie grup osób, specjalizujących się w zarabianiu na wierze $w$ to, iż są pośrednikami między bogami a grzesznikami: ,żebrzące klechy i wieszczbiarze do drzwi bogatych ludzi pukają i wmawiają, że jest u nich moc od bogów zesłana, żeby z pomocą ofiar i śpiewnych modlitw, jeżeli na kimś

\footnotetext{
23 Platon, op. cit., s. 54.

24 Ibidem, s. 56.
} 
ciąży zmaza grzechu albo na jego przodkach, zdejmować ją bardzo przyjemnie i przy uroczystych nabożeństwach" 25 .

Wizerunek bogów, wyłaniający się z greckiej mitologii, wskazuje jednoznacznie, że bynajmniej nie uczą oni Greków bezinteresownego przestrzegania zasad i czczenia wartości. Nie kto inny, a bogowie właśnie uczyli Greków, że bycie sprawiedliwym jest równoznaczne z osiąganiem korzyści. Potwierdzają to cytowane przez Platona fragmenty z dzieł Hezjoda i Homera, którzy upowszechniali mity z braku u Greków świętej księgi. Mówi się więc u obu poetów, że jeśli ktoś jest sprawiedliwy i bogobojny, to wówczas

„czarna ziemia mu niesie

Jęczmień i złotą pszenicę. Owoc gałęzie obrywa.

Jabłka się sypią wciąż i morze mu ryby przynosi”"26.

Niektóre z rzekomych korzyści, obiecywane przez poetów sprawiedliwym, wydają się Platonowi wręcz śmieszne, dużo jednak mówią o wyobrażeniu szczęścia wśród szerokich kręgów społeczeństwa. Na przykład, że po śmierci w Hadesie „urządzają wielkie przyjęcie dla pobożnych i ci tam w pieśni mają wieńce na głowach i nic, tylko piją już cały czas. Uważali widać, że najpiękniejsza zapłata za dzielność - to pijaństwo na wieki wieków”27 - konkluduje Platon.

Platon odnosi się z pogardą do ludzi tak źle myślących o bogach i tych, co to rozpowszechniają i wykorzystują. Ale czyż kiedykolwiek po Platonie, w tym nawet po porzuceniu przez Europejczyków religii pogańskich, oczekiwania wobec religii były inne, niż wówczas, a same religie bardziej zasadnicze wobec niesprawiedliwych, niż pogaństwo? Pytanie to jest, rzecz jasna, czysto retoryczne.

Platona, poczuwającego się do odpowiedzialności za wychowanie młodego pokolenia Greków, niepokoi nie tylko to, że bogowie nie uczą ludzi bezinteresownego stosunku do wartości, ale także to, że bogowie z mitów, którzy powinni być przecież dla śmiertelników wzorami do naśladowania, na żaden wzór się nie nadają. Bogowie są bowiem zawistni, mściwi, gwałtowni i wręcz czynią zło zarówno sobie nawzajem, jak i ludziom. Podobnie - herosi. Powstaje zatem pytanie, co powoduje ludźmi, że oddają im cześć? I tu Platon odkrywa społeczną funkcję strachu oraz siłę socjalizacji, czyli zagadnienia szeroko dyskutowane i badane w naszych czasach. Z tego bowiem, co napisano wyżej można wywnioskować, iż powodem, dla którego oddaje się bogom cześć, nie są ich zalety, ale strach przed ich wadami, najbardziej zaś przed ich mściwością. Platon nie chce jednak, żeby ludźmi powodował strach. Dlatego uważa, że mity, jako źródło wiedzy o moralnym postępowaniu, należy odrzucić, zaś na potrzeby państwa idealnego, postuluje napisanie mitów nowych, przekazywanych już w dzieciństwie następ-

\footnotetext{
25 Ibidem, s. 56.

26 Ibidem, s. 55.

27 Ibidem, s. 55.
} 
nym pokoleniom. Powodem jest to, że „to, czego nauczyliśmy się w dzieciństwie, zachowujemy w przedziwny sposób w pamięci" ${ }^{28}$, czyli dorosłych wychować się nie da. Ponieważ zaś wychowanym na starych mitach nie wystarczy moralne oburzenie ich treściami, żeby je porzucili, tak bowiem silne są wpływy socjalizacji pierwotnej, dlatego poszukuje on argumentów rozumowych, które jako jedyne mogą wesprzeć argumenty etyczne, uczynić je godnymi przyjęcia. Zatem odrzucenie starych mitów powinno być następstwem odpowiedzi na pytanie o to, czym w ogóle w sensie poznawczym jest mit?, czy też inaczej mówiąc, skąd słowa, którymi mit się posługuje, czerpią swoją prawdziwość? Platon był przekonany, że odpowiedź na nie wykaże nieprawomocność poznawczego statusu mitów. Jakich argumentów użył, o tym rzecz będzie szła poniżej.

Natomiast podsumowując to, co już zostało przedstawione warto zwrócić uwagę na stosowaną przez Platona metodologię. Otóż zauważmy, że jego rozważania rozpoczęły się od dyskusji etycznej, która doprowadziła do socjologicznych analiz faktycznego zachowania się ludzi. Z kolei zaś próba odpowiedzi na pytania o przyczyny takich zachowań przybrała charakter socjologii wiedzy i teologii zarazem. Niekorzystny pedagogiczny wydźwięk ,,pogańskiej teologii” doprowadził z kolei Platona do wniosku o konieczności podjęcia wysiłku zbudowania nowej teodycei. Ponieważ jej przeforsowanie, ze względu na trwałość socjalizacji, której jesteśmy poddani w dzieciństwie, wymaga mocnych argumentów, to konieczność ich zdobycia prowadzi Platona do rozpatrzenia epistemologicznego statusu mitu oraz sposobu, w jaki posługuje się on słowem. Te płynne przejścia od etyki do socjologii, teologii, pedagogiki, teodycei i epistemologii są odpowiedzią na pytanie, jak metodologicznie poprawnie badać tak faktycznie zazębiające się zjawiska. Śledzenie toku rozważań Platona na temat różnych zjawisk społecznych pozwala nam poznać i ocenić nie tylko jego poglądy w tych kwestiach, ale co najważniejsze, ocenić poznawczą wartość platońskiej metodologii nauk, która stanowi ich podstawę.

\section{Zmiana statusu słowa w filozofii starożytnej Grecji i jej implikacje}

W starożytnej Grecji miała miejsce największa przemiana sposobu funkcjonowania słowa, czyli podstawowego narzędzia myślenia. Platon był jej uczestnikiem i współtwórcą, my zaś (albo, mówiąc ściślej, niektórzy z nas) jesteśmy jej beneficjentami.

Na czym polegała ta przemiana? Trafnie opisuje ją filozof języka A. Gawroński, wskazując, że jej sednem i skutkiem było przeciwstawienie poezji nowo

28 Platon, Timajos, Warszawa 1986, s. 32. 
powstającej filozofii: „filozofia zaczęła się jako odkrycie nowych możliwości słowa $\mathrm{w}$ przeciwstawieniu do jego funkcji w poezji, której rodowód, bardziej antyczny, sięga półmroków prehistorii, czasów, kiedy baśniowej i mitycznej roli słowa jeszcze nie oddzielano świadomie od jego roli racjonalnej" ${ }^{29}$. Chodzi więc o przemianę roli słowa związaną z pełniejszą świadomością, że treści, do których przekazywania może ono służyć, zależnie od formy, w jakiej są przekazywane, posiadają niewspółmierny status heurystyczny. W tym nowym podejściu racjonalne, czyli uargumentowane logicznie użycie słowa, w odróżnieniu od sposobu używania słów w poezji i micie, jest poznawczo wyróżnione i wiodące. Więcej, dopiero w powiązaniu $\mathrm{z}$ racjonalnością słowo jest zgodne samo ze sobą, zgodne ze swą istotą. Krótko mówiąc, jest definicją, czyli wiedzą.

Snując rozważania o słowie, wyrazicielu wiedzy w mowie, Platon prowadzi nas nieuchronnie do rozważań o dwóch postaciach mowy - o przemowie (monologu) i rozmowie (dialogu), które się słowem posługują w inny sposób i z innym skutkiem. Według Platona, przemowa nie jest samowystarczalna. Potrafi głosić słowa, ale sama nie potrafi utrzymać ich w bliskim kontakcie z racjonalnością, rozumem, ponieważ z definicji nie konfrontuje ich treści z poglądami innych osób, ale brzmi pouczająco, wszechwiedząco. Tak właśnie brzmią treści podawane przez mit, które nie podlegają krytycznej analizie, są podawane ex cathedra, czyli do uwierzenia i zapamiętania. W celu poddania treści słowa nieustającej krytycznej analizie, zdaniem Platona, mowa powinna być dialogiem, a nie samotną przemową. Dialog jest naturalnym sposobem funkcjonowania mowy i miejscem przebywania/życia słowa. Nieprzypadkowo więc jedyną formą, której sam Platon używał, żeby pokazać tworzenie się myśli, jest dialog właśnie.

Cóż takiego daje nam dialog, czego nie daje monolog? Analizując sposób funkcjonowania słowa w twórczości Platona oraz innych filozofów greckich Alfred Gawroński słusznie wskazuje, iż w dialogu mowa staje się intersubiektywna, jest wychodzeniem poza siebie ku innemu, a płaszczyzną, na której mogą się spotkać rozmawiający, jest rozum. Ten „związek rozumu z mową, która nie «jest myślą prywatną», monologiem, lecz jest intersubiektywną wymianą, dialogiem wyrażono w greckim terminie logos. W dialogu słowo zatraca swoje mityczne i sakralne związki, przestaje być autonomiczną wypowiedzią lub tekstem, czymś, co można tylko przyjąć albo odrzucić. (...) Pytania i odpowiedzi w dialogu - w przeciwieństwie do wypowiedzi jednokierunkowej - zestawia się i powtarza, póki nie stwierdzi się, że miara, jaką się myśl określa, czyli słowo, jest wspólna wszystkim rozmawiającym" ${ }^{30}$.

\footnotetext{
29 A. Gawroński, Dlaczego Platon wykluczyt poetów z Państwa? U źródeł wspótczesnych badań nad jezykiem, Warszawa 1984, s. 18.

30 Ibidem, s. 19
} 
Kiedy w dialogu ustali się wspólną miarę dla wszystkich rozmawiających, można mieć przekonanie, że dotarliśmy do prawdy słowa. Ogólnie rzecz biorąc, prawdziwość zawartych w słowie treści ma dla słowa, w przekonaniu Platona, nie przypadkowy, lecz konstytutywny charakter. Inaczej mówiąc, prawdziwość nie jest cechą przydarzającą się słowu, jak chce pragmatyzm. Słowo fałszywe, to sprzeczność w definicji. Bez prawdziwego słowa nie ma wiedzy, nie ma społeczeństwa. Nawet prosta analiza potocznych wyrażeń języka polskiego takich, jak „dawać słowo”, „dotrzymywać słowa”, „złamać słowo”, „rzucać słowa na wiatr”, potwierdza filozoficzne przekonania Platona o związku słowa z prawdziwością i pozytywną społeczną wartością, czyli dobrem. Dawanie słowa i dotrzymywanie go to przecież podstawa wszelkich więzi społecznych. Stosując współczesne nam przykłady można powiedzieć, że jest ono fundamentem więzi społecznych poczynając od więzi osób prywatnych, umawiających się na randkę, po więzi społeczne, łączące klienta z reklamodawcą, i opierające się na przekonaniu, iż reklamodawca dotrzyma słowa i reklamowany produkt będzie posiadał cechy, które są w reklamie zachwalane.

Powiedzieliśmy wyżej, że słowo jest wyrazicielem sensu ${ }^{31}$, co jest pojęciem szerszym, niż pojęcie prawdziwości. Platon nie mówi tego wprost, ale wynika to jednoznacznie $\mathrm{z}$ analizy dialogów Platona, w których najczęściej dyskusje nie kończą się ustaleniem wspólnej definicji słów, a mimo to nie mamy wątpliwości, że prowadzone są z sensem. W tym kontekście, zadajmy sobie teraz pytanie, jak treść, sens słowa ma się do jego formy? Który z tych dwóch elementów, forma, czy treść, jest autonomiczna? Jeśli zaś obie mogą być autonomiczne, to jaki jest skutek przewagi formy nad treścią i odwrotnie, treści nad formą? Otóż, Platon, trafnie zauważa, że możliwa jest przewaga tak jednego, jak i drugiego elementu rozpatrywanej pary. Jednakże przewaga formy nad treścią ma dla tej ostatniej daleko idące negatywne konsekwencje. Kto bowiem stawia na formę wypowiedzi, na ogół czyni to w celu przemycenia treści, które inaczej podane, nie byłyby przyjęte. Panowanie nad formą wypowiedzi jest zatem panowaniem nad cudzą myślą. Funkcjonowanie słowa w micie i poezji polega właśnie na przywiązywaniu wagi przede wszystkim do formy słowa kosztem świadomej refleksji nad jego treścią, sensem. Tylko w filozofii/nauce treść słowa jest wiodąca, autonomiczna wobec jego formy. Tak powinno być również w praktyce, czyli w polityce i całym życiu społecznym. Słowo w tych dziedzinach nie powinno być kojarzone przede wszystkim ze swą szatą formalną. Ta umiejętność odróżnienia słowa od formy jego wyrazu jest warunkiem wstępnym racjonalnego myślenia sensu stricto.

\footnotetext{
31 W tym kontekście polecam rozważania George’a Friedmana z roku 2011, politologa i byłego doradcy do spraw bezpieczeństwa m.in. w National Defense University, o semantycznym chaosie stworzonym przez Prezydenta USA G. Busha na użytek jego polityki zagranicznej i skutkach tegoż. Zob. G. Friedman, Następna dekada. Gdzie byliśmy i dokąd zmierzamy, Kraków 2012, s. 92-93 i inne.
} 
Rozróżnienia sensu i formy wyrazu, treści i formy, mają w ocenie Platona daleko idące konsekwencje praktyczne/dydaktyczne. Oznacza bowiem, iż zapamiętywanie, na które kładzie nacisk mit i poezja, a następnie odtworzenie brzmienia jakiegoś twierdzenia nie jest tożsame ze zrozumieniem sensu wypowiedzianej frazy. Właściwym więc sprawdzianem rozumienia sensu słowa jest umiejętność wyrażania tegoż sensu na różne sposoby. Taką umiejętnością powinien się wykazać każdy myślący, dialogujący człowiek, niezależnie od wykonywanej przez siebie funkcji. Dotyczy to także definicji, które również powinniśmy umieć parafrazować. Człowiek koncentrujący się na formie słowa, może nieświadomie ulec urokowi niepożądanych treści.

Platon jest świadom, że umiejętność oddzielania formy od treści jest wymogiem czysto teoretycznym, normatywnym, nieosiągalnym (niestety) dla większości osób. Nawet rzeczywiste używanie słowa przez naukowców w jego funkcji poznawczej, a nie tylko informacyjnej, oznajmującej, komunikacyjnej, jak czynią to nie-naukowcy, jest w praktyce intuicyjne, czyli nie jest równoznaczne z rozumieniem, jak ono funkcjonuje i jak może być nadużywane. A właśnie nieświadome i świadome nadużywanie słów ma ogromne znaczenie społeczne/polityczne. Trzeba badać ten problem, żeby móc sobie z nim radzić.

Platon refleksji nad tym zagadnieniem poświęcił mnóstwo cennych analiz, których przyczynę i cel można wyrazić następująco: „Skoro całe nasze myślenie, (...) odbywa się w języku, dla obrony przed urojeniami, fikcjami niezbędne jest jak najtrzeźwiejsze badanie tego naszego powszechnego instrumentu - języka. (...) Jest to antidotum na zniewalanie ludzkiego umysłu przez teksty, których mechanizm przekonywania i kierowania myśli czytelnika ku takim, a nie innym konkluzjom, nie jest dla niego jasny. Mitomania zaś, uleganie mitom, może mieć w życiu skutki dla ludzi tragiczne"32. Nazywał on społeczeństwo starożytnych Aten sofistycznym, albowiem powszechne w nim było przekonanie, że ze słowem, ze sposobem posługiwania się nim, wiąże się „,największe dobro i źródło wolności dla ludzi, a jednocześnie władzy dla każdego w jego państwie" 33 . Koncentrowano się jednak na użyteczności słów, a nie ich prawdziwości. Tym dobrem, a zarazem źródłem wolności i władzy była bowiem dla większości umiejętność przekonywania, której uczyła retoryka. Czyniła to jednak w oderwaniu od refleksji moralnej nad celami przekonywania, jak i stosowanymi do tego środkami, czyli niejako stawiała się poza dobrem i złem. Jest to widoczne w wypowiedzi Gorgiasa, następnego po Trazymachu prekursorze quasi-kapitalistycznego stylu myślenia, postaci autentycznej, dodajmy. Dopytywany przez Sokratesa/Platona, co ma na myśli mówiąc o dobru w kontekście retoryki, uściśla on wprost, że myśli o użyteczności retoryki, czyli „o prze-

\footnotetext{
32 Z Kubiak, Przedmowa, [w:] A. Gawroński, op. cit., s. 9.

33 Platon, Gorgias, Warszawa 1991, s. 16.
} 
konywaniu słowami sędziów w sądach, członków rady w czasie narad, ludu na zgromadzeniach ludowych lub wszystkich innych zgromadzeniach obywateli". Reklamując też zalety retoryki, Gorgias podkreśla, że dzięki tej zdolności można zniewalać ludzi ${ }^{34}$. Na podstawie obserwacji wskazuje więc on na wszystkie negatywne cechy tzw. siły przekonywania, wcale ich tak zresztą nie oceniając. I w tym Sokrates/Platon widzi główny problem i powód do krytyki Gorgiasa.

Nastawiony na kierowanie się etycznością, a nie skutecznością, Sokrates/Platon studzi entuzjazm Gorgiasa wobec wszechmocy retoryki, wskazując, że w swej funkcji przekonywania retoryka jest skuteczna o tyle, o ile wzbudza w ludziach wiarę do pewnych racji, a nie wiedzę na ich temat, czyli posługuje się słowami w sposób niewłaściwy. Wiara bowiem, według niego, jest czymś gorszym od wiedzy, ponieważ opiera się li tylko na zaufaniu do mówcy, czyli na emocjach, a nie na wiedzy. Platon negatywnie ocenia fakt, że retoryka ograniczając się do budzenia zaufania do słów, a nie przekazywania wiedzy, całkiem świadomie wprowadza ludzi w błąd zarówno co do swoich celów, jak i swoich możliwości. Ludzie oczekują bowiem od retorów wiedzy i wierzą, że można ją przekazać szybko. Tymczasem przekazywanie wiedzy wymaga czasu i indywidualnego podejścia do ucznia, a tego mówca nie posiada. Dlatego, zdaniem Platona/Sokratesa, żaden mówca „nie byłby (...) w stanie pouczyć tak wielu ludzi w tak krótkim czasie" 35 . Retoryka więc oszukuje, że uczy. Nie uczy zaś, bo nie może.

Mocny, empiryczny argument przeciwko pozytywnemu stosunkowi do retorycznych umiejętności Sokrates upatruje także w tym, że ,gdy radzi się w mieście nad wyborem lekarza, budowniczego statków lub jakiegoś innego rzemieślnika - wówczas nikt nie uważa, że (dop. E. M.) - jest rzeczą mówcy dawać rady. Jest przecież oczywiste, że we wszystkich tych wypadkach mamy wybierać człowieka najbieglejszego w danym rzemiośle. Podobnie gdy chodzi o budowę murów, portów lub warsztatów okrętowych jedynymi doradcami są budowniczowie" 36 . Intelektualnym i moralnym skandalem jest dla Platona/Sokratesa twierdzenie Gorgiasa, które wskazuje, (niestety, słusznie skądinąd), że przytoczony wyżej argument działa w bardzo ograniczonym zakresie, a mianowicie tylko wówczas, kiedy powszechnie wiadomo wszystkim, kto jest ekspertem w jakiejś dziedzinie. W sytuacji, gdy takiej wiedzy się nie posiada, wyłączny wpływ na decyzje ludzi ma krasomówstwo. Platon wskazuje przy tej okazji, że najczęściej niezorientowany jest tłum. Brak wiedzy to wręcz konstytutywna cecha tłumu. Platon/Sokrates twierdzi wręcz: „tłum to znaczy ci, co nie wiedzą" ${ }^{37}$. Pojedynczy

\footnotetext{
34 Ibidem, s. 16

35 Ibidem, s. 20.

36 Ibidem.

37 Ibidem, s. 25.
} 
człowiek, kiedy czegoś nie wie, łatwiej zrezygnuje z osądu w jakiejś kwestii, niż grupa. Kiedy zaś ta sama jednostka staje się częścią tłumu, łatwo ulega perswazji mówcy. Le Bon, autor Psychologii tłumu, pochwaliłby Platona za dostrzeżenie tego faktu.

Zdaniem Platona/Sokratesa, retorykę moralnie dyskredytuje to, iż jest jej obojętne, co mówi i do kogo mówi, ważna jest wyłącznie skuteczność w wywoływaniu odpowiedniego wrażenia: ,retoryce nie jest potrzebna wiedza o tym, jak się rzeczy mają w rzeczywistości; wystarczy jej pewien rodzaj perswazji, którą wynalazła by wyglądać w oczach ignorantów na bardziej uczoną niż uczeni" 38 . Nie posiadanie wiedzy, a uchodzenie za osobę ją posiadającą, jest kluczem do sukcesu retora. Nie zmienia to faktu, że Platon odnotowuje popularność tej sztuki w starożytnych Atenach oraz chęć wielu osób do kształcenia się w niej. Z podobnymi zjawiskami mamy do czynienia obecnie. Skuteczność perswazji we wszystkich możliwych obszarach nie implikuje dzisiaj, jak i wówczas, konieczności przekazywania wiedzy prawdziwej. „Prawdziwa” jest tylko wiedza o sposobach skutecznego manipulowania.

Nie jest celem tego artykułu przytoczenie w tym momencie całości analiz, ilustrujących manipulacyjne posługiwanie się językiem w starożytnych Atenach. Istotne jest stwierdzenie, że sztukę manipulacji uprawiano już wówczas, że poprzedzała ona niemanipulacyjne posługiwanie się słowem oraz że można w tym zakresie odnotować wiele podobieństw między społeczeństwem ówczesnym a obecnym ${ }^{39}$.

Reasumując tę część artykułu, przygotowującą nas do zrozumienia wszechstronności kontekstu, w jakim toczą się rozważania Platona o ludziach pieniądza, odnotujmy, że według Platona:

- kompetencje poznawcze są równoznaczne z kompetencjami językowymi;

- istotą słowa jest racjonalność; jego funkcjonowanie poetyckie, czy mityczne, jest irracjonalne;

- właściwym sposobem funkcjonowania słowa jest dialog, rozmowa, czyli seria pytań i odpowiedzi, a nie monolog czy pismo;

\footnotetext{
38 Ibidem, s. 25-26.
}

39 Dla pełnego obrazu koncepcji słowa u Platona zwrócimy jeszcze uwagę na niebagatelną kwestię pisma. Pojawienie się słowa pisanego komplikuje rozważania o słowie jako takim, prowadząc nas do pytania o status pisma, które przecież wydaje się być najwyższym, niekwestionowanym osiągnięciem kultury. Czy słowu i wiedzy jest wszystko jedno, czy przyjmuje postać mówioną, czy pisemną? Odpowiedź Platona na to pytanie jest kategoryczna: słowo pisane oznacza, według Platona, śmierć twórczej myśli. Może ono w ograniczonym stopniu pełnić rolę pomocniczą, polegającą na przypominaniu, ale nie niesie żadnej samoistnej wartości dodanej w stosunku do pojęciowej zawartości słowa mówionego, używanego w dialogu. Można zatem powiedzieć, że jest bezużyteczne w dochodzeniu do prawdy. Platon wręcz podkreślał, że najwartościowszych swoich myśli nie powierzył pismu, zaś temu, co napisał, próbował nadać formę, jak najbardziej zbliżoną do żywego dialogu, zmierzającego do ujęcia wiedzy w postaci zdefiniowanych pojęć. 
- cel dialogu jest zawsze wspólnotowy, a nie indywidualny; polega on na znalezieniu wspólnego dla wszystkich rozmawiających sensu słów;

- dowodem na zrozumienie sensu słów jest oderwanie ich od ściśle określonej formy wyrazu;

- przywiązywanie wagi do sztywnej szaty słownej jest dowodem na oderwanie słowa od rozumu i uleganie czarowi formy;

- słowa wymagają czujności zarówno ze strony tych, którzy się nimi posługują, jak i tych, do których są kierowane; brak czujności wobec słuchanych słów prowadzi do urojeń, zniewolenia ludzkiego umysłu, kierowania go ku fałszywym konkluzjom, uleganiu manipulacji.

Pytanie, na które logicznie rzecz biorąc wypada teraz odpowiedzieć, brzmi, czy wszyscy ludzie są zdolni nauczyć się właściwego posługiwania się słowem? oraz - czy można sprawić, żeby byli do tego zdolni?

\section{Zróżnicowanie jednostek ze względu na kompetencje poznawcze/językowe i jego polityczne konsekwencje}

O ile współczesna ekonomia potrafi rozprawiać o zagadnieniach gospodarczych nie odwołując się wprost do koncepcji człowieka i państwa (jest to ważki, naszym zdaniem, zarzut metodologiczny), to dla Platona jest oczywiste, że zrozumienie istoty dobrego życia wspólnotowego wymaga wyciągnięcia teoretycznych i praktycznych wniosków z faktu, jacy są żywi ludzie. Eric Voegelin (1901-1985), konserwatywny myśliciel spoza głównego nurtu nauk politycznych XX w., który w Nowej nauce polityki podjął próbę odtworzenia refleksji w duchu platońskim, uważa, iż ,jest to zasada heurystyczna o pierwszorzędnym znaczeniu", ponieważ społeczeństwa są takie, jaki jest dominujący w nich typ ludzi ${ }^{40}$.

O ile nowożytność poszukiwała jednej, wspólnej wszystkim, natury człowieka, Platon rozpoczyna swe rozważania na ten temat od na pozór mało odkrywczej konstatacji, że „każdy się rodzi nie całkiem podobny do każdego innego, tylko się ludzie różnią z przyrodzenia: jeden się nadaje do tej roboty, a drugi do innej" ${ }^{41}$. Rzecz w tym jednak, że wnioski z niej wypływające są niezwykle doniosłe, tylko trzeba etycznej i politycznej dojrzałości, żeby je przyjąć do wiadomości i podporządkować im życie jednostek. Pierwszy zaś wniosek z niej wynikający brzmi: właśnie dlatego, że nie jesteśmy wszechstronnie uzdolnieni, potrzebna jest wspólnota, która pomoże nam uczynić bardziej znośnym ten defekt. Twierdzi więc Platon, że ,państwo tworzy się dlatego, że żaden

40 E. Voegelin, Nowa nauka polityki, Warszawa 1992, s. 65.

41 Platon, Państwo..., s. 63. 
z nas nie jest samowystarczalny, tylko mu potrzeba wielu innych" ${ }^{42}$. Ten wniosek wystarczająco ilustruje logiczny związek koncepcji człowieka z koncepcją państwa, oraz wskazuje, jaki w związku z powyższym powinien być faktyczny, praktyczny/etyczny związek człowieka z państwem. Mianowicie, powinien on być nierozerwalny, bo z faktycznej niesamowystarczalności człowieka nie da się logicznie wywnioskować, że człowiek będzie szczęśliwszy, jeśli państwa będzie mało (teza współczesnego neoliberalizmu) lub nie będzie go wcale. Dyskutować można tylko o tym, jakie konkretne formy może on przyjmować.

Z faktu przyrodzonej nierówności ludzi wynika nie tylko to, że jesteśmy sobie potrzebni, ale również pewna wskazówka „socjalizacyjna” i pedagogiczna, całkowicie sprzeczna ze współczesnymi praktykami w tym względzie. Skoro bowiem różnice są przyrodzone, to znaczy, że są nieusuwalne, z czego logicznie wynika, że nie może być celem dobrego państwa niwelowanie tych różnic, ale wręcz odwrotnie, podkreślanie ich i wyzyskiwanie dla dobra wszystkich. Wskazuje więc Platon na konieczność, opartej na naturalnych różnicach uzdolnień, „specjalizacji zawodowej” w celu profesjonalnego, mówiąc współczesnym językiem, podejścia do wykonywanych obowiązków. Jest on przekonany, że „więcej wszystkiego powstaje i to, co powstaje, będzie ładniejsze i łatwiejsze, jeżeli się jeden zajmie jednym, zgodnie ze swą naturą, we właściwej porze i mając głowę wolną od innych zajęć" 43 . Tak się rzeczy nie mają w państwach rzeczywistych, ale w idealnym państwie, gdzie w odróżnieniu od państwa rzeczywistego, ,znajdziemy szewca, który jest szewcem, a nie jeszcze sternikiem w dodatku, i rolnika, który jest rolnikiem, a nie sędzią, w dodatku do rolnictwa. I żołnierza, który jest żołnierzem, a nie spekulantem przy swojej sztuce wojennej" ${ }^{44}$. To pozycjonowanie ludzi zgodnie z posiadanymi zdolnościami, a zarazem kwalifikacjami, jest główną zasadą teoretyczną, którą według Platona trzeba mieć zawsze na uwadze, myśląc i mówiąc o idealnie funkcjonującym państwie/społeczeństwie.

Skoro, jego zdaniem, ludzie są przede wszystkim różni, a wszystkie różnice są użyteczne, to zasadnicze pytanie o miejsce człowieka we wspólnocie politycznej brzmi: które z różnic są najbardziej istotne oraz czym mierzy się ową istotność - odniesieniem do Boga, społeczeństwa/wspólnoty, czy samej jednostki? Z tych dwóch pytań najważniejsze jest ostatnie. Odpowiedź Platona na nie brzmi: wartość jednostki określana jest przez jej znaczenie dla wspólnoty społeczno-politycznej, bo chociaż polis powstała w celu przezwyciężenia niesamowystarczalności jednostek, z chwilą powstania stała się ona wartością samoistną, a nie wyłącznie służebną wobec poszczególnych jednostek. Zasadne więc jest pytanie, na czym owo znaczenie jednostek dla polis polega? Z tekstu

\footnotetext{
42 Ibidem, s. 62.

43 Ibidem, s. 64.

44 Ibidem, s. 95.
} 
platońskiego Państwa wynika, że na tym, jak bardzo człowiek swymi kompetencjami może się przysłużyć trwałości i doskonałości wspólnoty politycznej, albowiem, żeby niwelować skutki niesamowystarczalności ludzi, najpierw musi ona po prostu trwać.

W przekonaniu Platona, dobre służenie tym celom jest równoznaczne z posiadaniem zdolności do zdobywania wiedzy o tym, co jest dobre dla trwałości polis w każdej konkretnej sytuacji, a nie ogólnie. Jedno jest pewne, nie jest dobre dla niej szczęście jakiejś mniej, czy bardziej licznej grupy, lecz całego państwa ${ }^{45}$. Mówienie, że jeśli będzie dobrze ludziom bogatym, dobrze będzie i reszcie ludzi, jest na gruncie koncepcji Platona absurdalne.

Trzy z wszelkich możliwych predyspozycji Platon uznał za najistotniejsze: zdolność do racjonalnego myślenia, pożądanie rzeczy materialnych oraz skłonność do przemocy i agresji. Istnieją one w każdym $\mathrm{z}$ nas $\mathrm{w}$ różnym stopniu, ale jedna z nich jest zawsze wiodąca, stąd ludzi można podzielić na trzy kategorie. Dobrzy rządzący nie tylko sami o tym wiedzą, ale czynią wszystko, żeby również wszyscy obywatele mieli świadomość tego, że jedni z nas są rozumni, drudzy pożądliwi, a trzeci - popędliwi, i że z tego wynikają dalekosiężne wnioski i skutki. Spośród tych trzech różnic między jednostkami, kluczowe znaczenie dla ich pozycji społecznych powinny posiadać te wrodzone predyspozycje i uzdolnienia poznawcze, które najlepiej służą państwu. Nie są nimi pożądliwość i wojowniczość. Najpoważniejszy wniosek, wypływający z tego, to konieczność wykluczenia pożądliwych i popędliwych z rządzenia polis. Nie ma to nic wspólnego ze społeczną nieużytecznością tych grup. Oczywiście, społecznie są one jak najbardziej użyteczne. Chociaż jednak są użyteczne, nie są w stanie racjonalnie oceniać nawet własnych celów, do których dążą, ani środków, które do nich prowadzą, a co dopiero racjonalnie ocenić, na czym polega dobro polis. Weźmy pożądliwych, to nie rozum przecież, ale namiętna chęć posiadania powoduje nimi. Chciwy, nie może przestać gonić za pieniądzem, a agresywny nie może powstrzymać się od agresji i zemsty, nawet jeśli miałoby to doprowadzić do niepotrzebnych ofiar i zniszczeń. Chciwy nigdy nie uwierzy, że dobro państwa jest ważniejsze od dobra jednostki, a zwłaszcza jego osobistego dobra, jak również $\mathrm{w}$ to, że dobra jednostki nie mierzy się ani wyłącznie, ani przede wszystkim posiadanym przez nią bogactwem.

Racjonalność, będąca punktem wyjścia w uprawianiu nauki/filozofii jest też punktem wyjścia dobrego, politycznego/moralnego życia. Polityka i moralność bez refleksji nad poszczególnymi czynami ludzkimi w konkretnych sytuacjach nie jest, według Platona, godna swego miana, aczkolwiek jest możliwa. Dlatego uprawianie filozofii i kompetentne rządzenie polis wymagają identycznych kwalifikacji intelektualnych. O żadnym podziale na jakiś mityczny umysł ści-

45 Ibidem, s. 118. 
sły i humanistyczny nie może być mowy. Racjonalność wymaga wrażliwości na sens słowa, umiejętności dedukowania, logiczności i krytyczności w myśleniu oraz umiejętności dyskutowania, połączonej w sposób konieczny z gotowością do rezygnacji z przekonań, których się nie da rozumowo uzasadnić. Takich uzdolnień nie posiadają ani pożądliwi, ani popędliwi. Sprawdzianem rozumowych, a zarazem moralnych kompetencji jest odpowiedź na pytanie - co jest lepsze krzywdzić, czy być krzywdzonym? Według Platona, brzmi ona - być krzywdzonym $^{46}$. Ta odpowiedź byłaby nie do przyjęcia, ani dla jednych, ani dla drugich. Była zresztą skandalem również dla ówczesnej elity, ponieważ człowiek wolny, do tego właściciel niewolników, w powszechnym (nie tylko własnym) przekonaniu nie powinien był w żadnej sytuacji zachowywać się biernie ${ }^{47}$. Platon miał jednak wystarczająco dużo odwagi cywilnej, żeby tak właśnie twierdzić wbrew powszechnej ówcześnie opinii.

$\mathrm{Na}$ czym polegała ta odwaga cywilna z punktu widzenia naukowego poznania społeczeństwa, którego Platon niewątpliwie dokonywał? Odpowiedź na to pytanie trafnie ujął wybitny francuski socjolog Pierre Bourdieu, słusznie podkreślając, iż ,gdy chodzi o myślenie o świecie społecznym, związane z tym trudności są nie do przecenienia", albowiem rodząc się, wychowując i funkcjonując w danym społeczeństwie ulegamy ,potędze przedustanowionego (które - dop. E. M.) jest wpisane jednocześnie w rzeczy i umysły, występuje więc w kostiumie oczywistości, przechodzi niezauważone, jako rozumiejące się samo przez się"48. Zadanie socjologa polega na zerwaniu z tymi przedustanowionymi oczywistościami, a to jest niemożliwe bez przewrotu mentalnego w sobie samym. Przeczytaliśmy powyżej, że Platon badając, dlaczego ludzie myślą tak, jak myślą, dowodzi, że jest świadom istnienia tego przedustanowionego. Zrywając zaś na każdym kroku z oczywistościami, reprezentowanymi przez jego interlokutorów w dialogach, dowodzi, że on sam już im nie podlega w pełni. Można powiedzieć za Platonem, używając współczesnego języka, że wypowiedzi swoich adwersarzy uważa on za autoprezentacje różnych grup społecznych, a wchodząc z nimi w polemikę, przezwycięża je bez użycia przemocy. Dlatego też, poszukując adekwatnej nazwy dla dokonań badawczych Platona w tym zakresie, można powiedzieć, że uprawiał on socjologię refleksyjną i to na długo przed Pierre'm Bourdieu oraz że po względem metodologicznym był jej protoplastą.

Dodajmy, że m.in. z powodu tego przełomowego postawienia etycznej kwestii krzywdzenia Platon był tak bardzo ceniony przez średniowiecznych filozofów chrześcijańskich, którym znany był nakaz Jezusa nadstawiania drugiego policzka,

\footnotetext{
46 Platon, Gorgias..., s. 73.

47 Dokładnie tak widział obowiązek pana służący opisany przez Witolda Gombrowicza w Ferdydurke!

48 P. Bourdieu, op. cit., s. 252.
} 
kiedy ktoś nas uderzy. Ale nie tylko na tym polega powinowactwo między średniowiecznymi teologami a Platonem, lecz również na roli, które przypisywał logicznemu rozumowaniu. Żyjący w XIII w. św. Tomasz z Akwinu, mimo posiadania Dekalogu, którego nie mieli starożytni Grecy, uważał, że bycie moralnym w przypadku chrześcijanina wymaga również wysokich kompetencji intelektualnych. MacIntyre stanowisko Tomasza w tej kwestii relacjonuje następująco: „Zastosowanie podstawowych zasad do konkretnej sytuacji wymaga szeregu dodatkowych zdolności: tak dedukowania $\mathrm{z}$ uniwersalnych i ogólnych podstawowych zasad, zasad bardziej szczegółowych, bardziej bezpośrednio odnoszących się do konkretnych typów sytuacji, jak i wyciągania z obu rodzajów zasad konkretnych sądów praktycznych, dotyczących tego, co powinno być uczynione tu i teraz albo w jakimś konkretnym układzie okoliczności, który pewnego dnia, choć jeszcze nie dziś, może się stać naszym «tu i teraz»" ${ }^{49}$. Podkreśla więc w nim wyraźnie, że wiedza o tym, co dobre, ma charakter dedukcyjny, a nie empiryczny, mimo że stosuje się do empirii oraz jest konkretna, a nie ogólna. Warto także podkreślić, że według Tomasza z Akwinu, nie każdy jest zdolny taka wiedzę posiąść, a przyczyn tego ograniczenia kompetencji intelektualnych i moralnych zarazem może być kilka. Za najważniejsze Tomasz uważa: znieprawienie rozumu wskutek jakiejś namiętności, złe nawyki, złe usposobienia natury ${ }^{50}$. Podobnie, jak Platon, Tomasz jest przekonany, że tych wad, prowadzących do zachowania niemoralnego „nie da się wytępić nawet przez najlepsze wychowanie zgodne z rozumem" ${ }^{51}$. Jako chrześcijanin ucieka się do łaski boskiej, która jako jedyna pozwala się wyzwolić z rzeczonych ograniczeń.

Reasumując, w czasach Platona w pogańskiej Grecji, podobnie jak przez setki lat po nim w społeczeństwach chrześcijańskich, ludzi nie traktowano, jak równych, ale określano ich przez miejsca i role w społeczeństwie. Platon więc nie wymyślił zróżnicowania społecznego, a tylko otwarcie zachował tę zasadę w swojej normatywnej polis. W stosunku do zastanej rzeczywistości zmienił jednak zasadniczo kryteria, według których powinno rozmieszczać się ludzi w polis. Stały się nimi przyrodzone zdolności jednostek i możliwość ich wykorzystania dla dobrostanu polis, czyli najwyższego dobra wspólnego. Wśród tych zdolności wyróżnione miejsce zajmuje umiejętność zdobywania o wiedzy o tym, co to jest dobro w ogóle, a dobro polis w szczególności. Zaś zdobywanie, przekazywanie i praktyczne wykorzystanie tej wiedzy wymaga wysokich kompetencji językowych.

\footnotetext{
49 A. MacIntyre, Czyja sprawiedliwość? Jaka racjonalność?, Warszawa 2007, s. 271.

50 Ibidem, s. 266.

51 Ibidem, s. 266.
} 


\section{Miejsce „robiących pieniądze” w społeczeństwach historycznych oraz w idealnym społeczeństwie Platona}

Platona interesowały nie pieniądze, ale ludzie je zarabiający i przywiązujący do nich nadmierną wagę. Ponieważ zaś uważał, że cechy poszczególnych grup społecznych oraz rodzaj wykonywanych przez nie zajęć mają wpływ na ustrój polityczny, to odpowiedź na pytanie, jakie cechy posiadają kupcy i jak wpłynęłyby one na polis, gdyby pożądliwi posiadali w społeczeństwie władzę, interesowało go najbardziej.

Już w czasach Platona greccy kupcy dominowali w handlu europejskim. To oni wymyślili sprzedaż z odroczoną płatnością, pożyczkę bodmeryjną (pod zastaw statku lub ładunku), hipotekę, zastaw, poręczenie, a nawet ubezpieczenie (nota bene, najpierw przeciwko ucieczkom niewolników!) ${ }^{52}$. W republice rzymskiej dodano do tego zestawu osobowość prawną dla spółek zwanych publicani, która ponownie pojawiła się w Europie dopiero w XIX w. Są to narzędzia ekonomiczne wykorzystywane po dziś dzień. Nie znaczy to jednak, że greccy kupcy stworzyli kapitalizm. Istniał tam rynek, ale nie gospodarka rynkowa.

Dobry, teoretyczny grunt dla rozważań Platona o miejscu kupców w idealnej polis stanowił fakt, że starożytni Grecy dostrzegali zasadniczą różnicę między ekonomiką i chrematystyką. Żadna z tych nauk nie przypominała jednak nauki ekonomii w dzisiejszym rozumieniu słowa. Obie natomiast miały silne podłoże etyczne $^{53}$, czyli analizowały działalność w obu dziedzinach pod kątem tego, co czyni ona drugiemu człowiekowi i polis. Pierwsza była nauką o gospodarstwie domowym, czyli o własności, która była oceniana pozytywnie, druga dotyczyła sztuki bogacenia się, którą oceniano negatywnie, ponieważ bogaci mogli być przecież również niewolnicy. Jak słusznie podkreśla Hannah Arendt, dla Greka „bogactwo i własność nie tylko nie są tym samym, ale mają inną naturę”. Dla podkreślenia zaś, że i w naszych czasach rozróżnienie to ma sens, dodaje słusznie: „Obecne pojawienie się bogatych, faktycznie lub potencjalnie, społeczeństw, które jednocześnie są w istocie bezwłasnościowe, ponieważ bogactwo każdej jednostki składa się z jej udziału w corocznym dochodzie społeczeństwa jako całości, jasno pokazuje, jak niewiele wspólnego mają obie te rzeczy" ${ }^{54}$. W starożytnej Grecji uświęcona była własność, a nie bogactwo, a starożytny pan domu i zarazem właściciel niewolników, patrząc ze współczesnego punktu widzenia, był raczej rentierem, a nie przedsiębiorcą. „Można by rzec, że względy statusu przeważały nad racjonalizmem ekonomicznym" ${ }^{55}$ we współczesnym sensie słowa.

\footnotetext{
52 J. Attali, Żydzi, pieniadze, świat, Warszawa 2003, s. 48.

53 A. Giardina, Kupiec, [w:] Człowiek Rzymu, Warszawa 2000, s. 305-307.

${ }^{54}$ H. Arendt, Kondycja ludzka, Warszawa 2000, s. 68.

55 Grecja klasyczna 500-323 p.n.e., Warszawa 2002, s. 47.
} 
Mimo to, istnieli nie tylko właściciele gospodarstw ziemskich, ale również bogacze, i fakt ten wymagał przemyślenia, a nie prostego odrzucenia. Bogacenie zaś kojarzyło się z kupiectwem i analiza zachowań tej warstwy społecznej interesuje nas tutaj najbardziej. W Atenach niemal wszyscy bankierzy, czyli osoby wymieniające pieniądze i udzielające kredytów, byli metojkami ${ }^{56}$, czyli ludnością napływową, stąd interesują nas oni tutaj mniej, ponieważ nie mogli sprawować władzy politycznej, a tym samym narzucać własnego, „bankierskiego” systemu wartości.

$\mathrm{Z}$ etycznego punktu widzenia dla Platona w bogactwie ważne były dwie rzeczy - jak się je zdobywa oraz jak się je wydaje. Według niego, żadnej z tych rzeczy nie da się zrobić zgodnie z etyką. „Kto wydaje na piękne cele a zyski ciągnie tylko ze sprawiedliwych źródeł ten niełatwo dojdzie kiedykolwiek do znacznego bogactwa - pisze Platon, a na pocieszenie dodaje: ani też nie popadnie w wielkie ubóstwo" 57 . Te dwie kwestie - nieodpowiedni sposób zdobywania i równie nieodpowiedni sposób posługiwania się bogactwem są implikowane samą jego istotą.

W pierwszej księdze Państwa Platona, kiedy Sokrates wypowiada się na temat niesamowystarczalności jednostek i konieczności powstania państwa, które by ten deficyt pojedynczej osoby usunęło, wśród wielu kategorii zawodów wymienia kupców. Uznaje on, że są niezbędni, o czym przesądza fakt, że założyć państwo ,gdzieś w takim miejscu, gdzie nic nie trzeba będzie dowozić, to po prostu rzecz niepodobna, (...), zatem będzie potrzeba jeszcze innych ludzi też, którzy by z innego miasta przywozili, co trzeba"58. Poza tym w samym państwie ludzie, wytwarzający różne rzeczy i usługi, „będą sprzedawali i kupowali, więc z tego nam się zrobi rynek i pieniądz, znak służący do wymiany" 59 . Dla ścisłości podkreślmy, że nie każdego sprzedającego Platon nazywa kupcem. Tych, którzy nie opuszczają miasta/państwa, handlując stale „naokoło rynku”, nazywa on kramarzami, kupcami zaś tych tylko, którzy podróżują poza nie. I chociaż kupców ocenia wyżej od kramarzy obie te kategorie osób nie są zdolne do racjonalnego posługiwania się językiem/mową. Kto zaś nie jest racjonalny, ten jest irracjonalny. Główną wadą obu tych kategorii ludzi jest brak umiaru, co zresztą dotyczy nie tylko ich.

Powodowany namiętnym stosunkiem do rzeczy i pieniędzy kupiec traktuje mowę wyłącznie jako środek do osiągnięcia swoich celów. Traktowana jest więc ona, podobnie jak u wspominanych wcześniej retorów, jako narzędzie perswazji, czy wręcz manipulacji klientem. Spełniając tę rolę mowa oderwana zostaje od prawdy i dobra, czyli od tego, co jest jej rzeczywistą istotą. Platon wyciąga z tego

\footnotetext{
56 Ibidem, s. 61.

57 Platon, Prawa..., s. 438

58 Idem, Państwo..., s. 64.

59 Ibidem, s. 65
} 
faktu wniosek, że uczciwa wymiana handlowa powinna być wymianą niemą, czyli odbywać się bez użycia mowy, a nawet więcej, bez obecności kupca. Skoro bowiem kupiec nie jest zdolny do racjonalnego posługiwania się słowem, nie jest też zdolny do prowadzenia dialogu. Zatem w całej operacji wymiany handlowej jego obecność, czyli to, co mówi, oraz jak mówi, są źródłem fałszu, a nie prawdy.

Nikt z nas nie ma pewnie wątpliwości, że krytyka dokonana przez Platona nie straciła na aktualności również dzisiaj . Dominująca w wymianie handlowej w czasach nam współczesnych reklama nie jest przecież odpowiedzią na naturalne potrzeby człowieka, ale jest tych potrzeb kreatorem, jest perswazją, narzucaniem poglądów, a bardzo często również zwykłą manipulacją. Tym samym są wszelkie chwyty socjotechniczne, tylko pozornie odwołujące się do ludzkiej racjonalności, w rzeczywistości zaś żerujące na ludzkiej irracjonalności. Jak słusznie zauważa A. Gawroński, ,irracjonalizm (we współczesnym sensie) powstaje wszędzie tam, gdzie człowiek nie przemawia do drugiego człowieka jak równy do równego, lecz jak wyrocznia, która wie i poucza" ${ }^{60}$. Jasne, że tego typu postawy są obecnie powszechne w takim samym stopniu, jak w czasach Platona, a dostępne nam sposoby komunikowania się nie wpłynęły na treść, lecz co najwyżej na szybkość przenoszenia irracjonalnych form wypowiedzi ze sfery handlowej do polityki (marketing polityczny).

Platon nie był odosobniony w krytyce kupców. Podzielał poglądy całego ówczesnego społeczeństwa, uznane zresztą, co może wydawać się dziwne, nawet przez niektórych kupców. Kupcy detaliczni, kramarze, byli uważani za gorszych od kupców dalekomorskich, ponieważ czerpanie zysków z zakupu czegoś taniej i odsprzedawania drożej oceniano jako oszustwo. Powszechnie uważano ich umysły za dwulicowe i zepsute. Niechęć społeczeństwa wobec nich była tak wielka, że w Atenach „obowiązywała norma zakazująca wypominania zawodu tym, którzy praktykowali ergasia na agorze"61. Kupcy dalekomorscy przynajmniej wykazywali się odwagą, płynąc za towarami w dalekie kraje. Natomiast w przypadku detalistów ,chytrość - pierwiastek zła immanentnie tkwiący w handlu występowała w stanie czystym" 62 .

$\mathrm{O}$ podzielaniu podobnych negatywnych ocen przez niektórych kupców świadczy analiza treści napisów na ich nagrobkach. Pozwalają one odczytać, z braku innych źródeł pisanych, elementy pewnej autoprezentacji kupców. Kupcy dalekomorscy, akceptujący punkt widzenia kultury dominującej, kładą duży nacisk na swoją odwagę, podając liczbę odbytych podróży morskich, kupcom detalicznym pozostaje wskazanie, że byli hojni lub wręcz, że pod koniec życia rozdali wszystkie swe bogactwa ${ }^{63}$.

\footnotetext{
60 A. Gawroński, op. cit., s. 35-36.

61 A. Giardina, op. cit., s. 317.

62 Ibidem, s. 316.

63 Zob. A. Giardina, op. cit., s. 322-323.
} 
Platon przypisywał bogactwu jako takiemu negatywne cechy, będąc przekonanym o jego destrukcyjnym wpływie na stabilność państwa. Przede wszystkim był on przekonany, że w większości ludzi drzemie dusza rentiera, czekająca tylko na możliwość zawładnięcia ludzkimi zachowaniami. Rentierstwo zaś oceniał negatywnie z punktu widzenia potrzeb polis. Jakie negatywne skutki przypisywał on rentierstwu? Otóż uważał, że bogactwo psuje niezbędnych w polis rzemieślników, gdyż wzbogaciwszy się nie chcą oni więcej wykonywać swojego fachu, albo zaczynają go wykonywać niedbale przez co pozbawiają innych członków społeczeństwa zawodów niezbędnych do zaspokajania ich potrzeb. Rentierstwo zatem powoduje, że nie może być realizowany cel, dla którego ludzie połączyli się we wspólnotę. Innym problemem związanym z bogactwem jest tworzenie przez niego nędzy. Bogaci wzbudzają u ludzi potrzeby niekonieczne, szkodzące ciału i duszy, ,,jeżeli chodzi o rozum i o panowanie nad sobą" ${ }^{4}$, a następnie „kto się im tylko da, temu wpuszczają pieniądze, (...), a od kapitału ściągają sobie procenty wielokrotne i pomnażają $\mathrm{w}$ ten sposób ilość trutniów i nędzarzów w państwie" 65 . Z punktu widzenia trwałości państwa bogactwo i nędza są równie destrukcyjne, „bo jedno wyrabia zbytek, lenistwo i dążności wywrotowe, a drugie upadla i rodzi zbrodnię, oprócz dążności wywrotowych”"6. Natomiast, ,,jeśli we współżyciu ludzi ani bogactwo nie bierze udziału, ani bieda, wtedy się chyba najlepsze wytwarzają charaktery i obyczaje" ${ }^{67}$. W cytowanych fragmentach Platon, reprezentant warstwy dominującej, w zwięzłej formie demonstruje elementy dyskursu godnościowego (,nędza upadla”), wskazuje na przyczyny przestępczości oraz przyczyny nastrojów rewolucyjnych. Każde z tych zjawisk znamy ze współczesności, każde z nich, według Platona, będąc niekorzystnym dla trwałości wspólnoty, nie jest jednak nieuchronne. Może zostać usunięte lub znacznie ograniczone, jeśli zadba się o zmniejszenie różnic między bogatymi a biednymi.

Dodajmy, że nie tylko konkretne przejawy nierówności w postaci nędzy i bogactwa są niebezpieczne dla stabilności polis. Według niego, rozkłada państwo każda duża nierówność z satysfakcji życiowej, czyli „kiedy jedni cierpią niewymownie, a drudzy się bawią znakomicie przy sposobności tych samych zdarzeń w życiu państwa i tych, którzy w państwie żyją"68. Zauważenie przez Platona faktu relacyjności cierpienia i nędzy, które staje się bardziej nieznośne, jeśli $\mathrm{w}$ tej samej sytuacji inni się cieszą, jest tym bardziej godne podkreślenia, że nawet w pełni dojrzała socjologia nie od razu zwróciła uwagę na konieczność badania tego zjawiska i na jego konsekwencje.

\footnotetext{
64 Platon, Państwo..., s. 268.

65 Ibidem, s. 265.

66 Ibidem, s. 119.

67 Platon, Prawa..., s. 386.

68 Idem, Państwo..., s. 164.
} 
Wracając do bogatych, pytanie, które Platon zadaje sobie w związku z nimi brzmi: Co oprócz niewiedzy i manipulacyjnego używania języka jest niebezpiecznego w zachowaniu się ludzi bogatych? Odpowiedź na nie jest krótka - arogancja. Arogancja jest cechą charakteru wpływającą destrukcyjnie na trwałość państwa. Wyraża się ona w tym, że ludzie bogaci mają tendencję do przekraczania miejsc wyznaczonych im w państwie przez ich zdolności i potrzeby innych. Mierzą oni siły na zamiary, a nie na odwrót. Kiedy bowiem ,jakiś rzemieślnik albo inny groszorób wzbije się w dumę na tle swego bogactwa, albo wpływów, albo siły, albo czegoś innego w tym rodzaju, i zacznie przybierać postać wojskowego, albo ktoś z wojskowych przybierze postać radnego i strażnika, chociaż tego nie godzien, i ci ludzie pomieniają z sobą narzędzia i zaszczyty, albo gdy jeden i ten sam człowiek spróbuje to wszystko robić równocześnie, wtedy (...) taka zamiana i takie łączenie zawodów, to zguba dla państwa" ${ }^{69}$. Państwem powinni rządzić mądrzy, a nie bogaci. Kto zdobył bogactwo, posiadał wiele cech niezbędnych do jego zdobycia, ale nie mądrość, która jest konieczna do rządzenia państwem. Kompetencje w jednej sferze nie oznaczają kompetencji w sferach innych - oto platońska zasada, której nie dość powtarzać. Mówiąc ironicznie w ślad za Platonem, ,niebezpiecznie jest (...), kiedy się głupi modli, raczej niechby mu się stało coś przeciwnego, niż chce" 70 .

Ktoś mógłby powiedzieć, że sytuując rzemieślników, lichwiarzy i kupców poza wpływami na rządzenie polis, Platon mijał się z rzeczywistością. Jednakże historycznie rzecz biorąc jednoznacznie negatywny stosunek do ludzi parających się robieniem pieniędzy obserwujemy aż do przełomu wieku XV i XVI. Religia chrześcijańska, mając podobny stosunek do pieniędzy, jak Platon, do tego czasu skutecznie nie pozwalała osobom z nimi związanym na odgrywanie wiodącej roli politycznej. Trafnie scharakteryzował tę sytuację Immanuel Wallerstein, pisząc: „kapitalistyczna warstwa przedsiębiorców istniała w Europie zachodniej, tak jak i w innych częściach globu, od dawna. (...) Jednak we wszystkich poprzednich systemach historycznych istniały potężne siły, które ograniczały ich swobodę działania i nie pozwalały uczynić ich motywacji (podkreślenie moje - E. M.) definicyjną cechą systemu. Tak było też w chrześcijańskiej Europie, gdzie (...) instytucje kościoła katolickiego toczyły nieustanną walkę z «lichwą». W chrześcijańskiej Europie, podobnie jak wszędzie na świecie, kapitalizm był ideą nieprawowitą, a jego praktyków tolerowano jedynie na względnie niedużych polach świata społecznego"71. Inaczej mówiąc, pogoń za zyskiem, jako wiodąca motywacja działalności ludzi była tolerowana, ale nie pochwalana. W sporządzonych przez średniowiecznych teologów chrześcijańskich spisach zawodów kupiectwo

\footnotetext{
69 Ibidem, s. 134.

70 Platon, Prawa..., s. 395.

71 I. Wallerstein, Koniec świata jaki znamy, Warszawa 2004, s. 163.
} 
i bankierstwo uznawane są za zawody „nieuczciwe” i „nieczyste”. „Zawód kupca nie jest Bogu miły", twierdzili teologowie, a akt kupna-sprzedaży rzadko jest wolny od grzechu ${ }^{72}$. Natomiast prawdziwym moralnym horrendum było dla nich pożyczanie na procent. Według powszechnych w średniowieczu wierzeń, pożyczanie na procent skazuje na potępienie nie tylko dusze lichwiarzy, ale także ich dzieci, o ile odziedziczyły one zdobyte w ten sposób bogactwo.

Beznadziejność moralnej sytuacji lichwiarza w oczach Boga trzynastowieczny teolog, Bertold z Ratyzbony opisuje następująco: „możesz otrzymać krzyż od papieża, walczyć z poganami, zdobyć Święty Grób i umrzeć w Bożej sprawie, a nawet zostać pochowanym w Świętym Grobie, a i tak mimo całej twej świętości dusza twoja jest zgubiona"73.

Bertold z Ratyzbony krytykował także nierówny podział dóbr. Nie widział dla niego uzasadnienia w świętości własności. Głosił, że Bóg stworzył ich dostateczną ilość, by wszyscy mogli się wyżywić, ale są one źle dystrybuowane. Zarówno on, jak i Tomasz z Akwinu oraz dużo później John Locke, twierdzili, że wszelkie dobra są tylko powierzone przez Boga ludziom. Nie są oni ich właścicielami, ale zarządcami, i będą musieli po śmierci zdać Bogu sprawę z tego, jaki z nich zrobili użytek.

Przekonanie o słuszności wyżej wymienionych tez powodowało, że do obsługi kapitalistycznych elementów działalności gospodarczej chrześcijańscy władcy sprowadzali Żydów. Korzystając z ich obecności nie przestawali jednocześnie propagować negatywnego stosunku do kupiectwa czy bankierstwa. Ta negatywna ocena przylgnęła do Żydów na stałe, ale niektórzy ludzie byli świadomi, że potępienie Żydów i dotykające ich cyklicznie pogromy, w rzeczywistości nie mają szczerego podłoża religijnego. Jak podaje Kronika Strasburga, pochodząca z przełomu XIV i XV w., ,gdyby Żydzi byli biedni, a panowie nie byli u nich zadłużeni, nie palono by ich" "74. Dowodem na to jest fakt, iż w średniowieczu pogromy dotykały również kupców włoskich.

Skrajnym przykładem poświęcenia możliwych szans ekonomicznych w imię wiary przedstawia sobą w Europie Portugalia. W XV w., licząca milion mieszkańców Portugalia sprawowała kontrolę na trzema czwartymi drogi okrążającej świat - od Brazylii po Japonię. Świadczyło to o znajomości techniki i posiadaniu określonej wiedzy. Będąc jednak bardzo pobożnymi, Portugalczycy w 1506 r. dokonali pogromu Żydów, wytępili astronomów, bo w większości byli oni Żydami, a próby stworzenia astronomii chrześcijańskiej nie powiodły im się, ponieważ wszystkich zdolnych astronomów podejrzewano, że są Żydami. Zresztą jak można było uprawiać astronomię skoro do 1746 R. w Portugalii zakazani byli Koper-

\footnotetext{
72 A. J. Guriewicz, Kupiec, [w:] Człowiek średniowiecza, red. J. Le Goff, Warszawa 2000, s. 309.

73 Ibidem, s. 315.

74 A. Guriewicz, op. cit., s. 314
} 
nik, Galileusz i Newton, a portugalscy studenci przestali wyjeżdżać za granicę. Wszystkie prasy drukarskie były w rękach duchownych, a w podległej Portugalii Brazylii były w ogóle zakazane aż do 1807 r. W rezultacie Portugalczycy utracili pierwszeństwo w nawigacji, która niegdyś była ich domeną, a ich ściśle tajne mapy stały się bezużyteczne, bo lepsze stworzyli Hiszpanie ${ }^{75}$. Podkreślmy raz jeszcze, opisany tu przypadek Portugalii jest skrajną postacią ingerencji wartości w świat gospodarki. Podobną, chociaż nie związaną z chrześcijaństwem ingerencję przeżyły również Chiny w XV wieku ${ }^{76}$.

Mimo że teologia potępiała kupiectwo i bankierstwo, wiek XIII i pierwsze trzydziestolecie XIV W. w Europie można uznać za rozwój obu tych działalności gospodarczych. W wielu miastach, np. we Florencji, Wenecji, czy Genui, kupiectwo przejęło władzę i nazwało się ludem. Inaczej niż we współczesnych skojarzeniach, za lud uważana była część społeczeństwa, żyjąca za sprzedaży, ci zaś, którzy żyli z pracy własnych rąk nie byli uważani za lud, lecz za „niosące zarazę masy”, albo „niebezpieczny tłum”"77.

Jednak prawdziwa zmiana stosunku do elementów, składających się na system zwany kapitalizmem, jak już sygnalizowaliśmy wyżej, nastąpiła na przełomie XV i XVI w. Wówczas to na bazie kryzysu religijnego wywołanego walką katolicyzmu z protestantyzmem, którego wyrazem było ustanowienie ostatecznie politycznej zasady „,czyj kraj, tego religia”, religia jako nośnik wartości odeszła na plan drugi, na pierwszy zaś wyszła racja stanu. Racja stanu władców polegała na tym, żeby być bogatymi. Oznaczało to powstanie myślenia merkantylistycznego, które propagowało jako dobro samo w sobie popieranie rozwoju kapitalistycznych sfer gospodarki. Zgadzamy się tutaj z metodologicznym podejściem Jonathana Israela, dla którego merkantylizm nie jest zbiorem „pojęć o charakterze czysto ekonomicznym”, lecz jest nowym podejściem politycznym do kwestii społeczno-politycznych. W takim ujęciu merkantylizm oznacza „zamierzone dążenie do realizacji ekonomicznych interesów państwa bez względu na zastrzeżenia wynikające $\mathrm{z}$ istniejących praw, przywilejów, tradycji czy religii" 78 . Mamy tutaj do czynienia, jak u Platona, ze świadomym wypracowaniem innych niż dotychczas wyobrażeń o roli i funkcjach państwa. Cel państwa nowożytnego był jednak zasadniczo odległy od celu idealnej platońskiej polis. Było nim bowiem planowe, ,świadome dążenie do gospodarczej pomyślności państwa przez to właśnie państwo"79. Teoria państwa i instytucji politycznych wyprzedzała więc nową praktykę działań politycznych. Powstaje pytanie, czy przez to, że do

75 Zob. D. S. Landes, Bogactwo i nędza narodów. Dlaczego jedni sa tak bogaci, a inni tak ubodzy, Warszawa 2005, s. 162.

76 Zob. ibidem, s. 122, 257.

77 A. Guriewicz, op. cit., s. 323-324.

78 J. I. Israel, Żydzi europejscy w dobie merkantylizmu (1550-1750), Warszawa 2009, s. 28.

79 Ibidem, s. 29. 
pomyślności gospodarczej dążyło państwo, działalność ta utraciła wszystkie negatywne cechy, przypisywane jej przez całe tysiąclecia? Można się zgodzić z poglądem Jonathana Israela, że „merkantylizm i narodziny polityki propaństwowej (raison d'État), której zresztą był on częścią, wywołały proces, który można by określić mianem pierwszej wielkiej emancypacji w dziejach Europy, to jest stopniowego wyswobadzania się z ograniczeń przeszłości”"80. Emancypacja całych warstw ludzi wydaje się być, czymś pozytywnym. Pytanie jednak co i od czego wyswobodzono. W rzeczywistości nie wyswobodzono ludzi. Wyswobodzeniu od ograniczeń uległa działalność kupców i bankierów w ogóle, a zajmujących się nią Żydów w szczególności, ale nie sami kupcy, bankierzy, czy Żydzi. Było to więc wyzwolenie działalności gospodarczej typu kapitalistycznego od ograniczeń natury moralnej, od odpowiedzialności za jej społeczno-polityczne skutki.

Myśliciele świeccy do lat 70. XVI w. wciąż oceniali bogactwo i pieniądze negatywnie. Michał Rozbicki podkreśla, że nawet w przodującej ekonomicznie szesnastowiecznej Anglii „pojęcie zysku jako wartości pozytywnej samej w sobie było wciąż nowością i często kłóciło się ze średniowiecznymi normami religijnymi określającymi «słuszną cenę»"81. Miłość do pieniędzy Tomasz Hobbes (1588-1679), wybitny myśliciel XVII w., nadal nazywał „,rzeczą brzydką"\$2, podkreślał, że mądrość i bogactwo nie chodzą parami, a mądrość należy cenić wyżej. Był również świadom tego, że bogactwo i władza nie sprzyjają etycznemu postępowaniu ludzi. Mimo niesprzyjającej bogaceniu się atmosfery, dwa wieki później, w roku 1776, Adam Smith odnotowywał w Badaniach nad natura i przyczynami bogactwa narodów, polityczny sukces bogacących się, pisząc że w Anglii „głównymi architektami polityki” są ludzie, którzy posiadają społeczeństwo, czyli „kupcy i wytwórcy”"83.

W odróżnieniu od władców, którzy poradzili sobie z akceptacją kapitalistycznych elementów w gospodarce, sekularyzując całokształt działalności państw, sposobem na radzenie sobie jednostek $\mathrm{z}$ dysonansem poznawczym między religią chrześcijańską a działalnością gospodarczą typu kapitalistycznego było powstanie specyficznych odmian protestantyzmu - kalwinistów, anglikanów, kwakrów, mennonitów i innych. Związki między religijną etyką wymienionych odłamów chrześcijaństwa i kapitalizmem były ewidentne, tyle że tym razem, w odróżnieniu od całej przeszłej historii, wpłynęły na jego rozwój pozytywnie, stymulująco, a nie negatywnie, hamująco. Pisał o tym obszernie Max Weber w swojej słynnej

\footnotetext{
80 Ibidem.

81 M. J. Rozbicki, U źródeł brytyjskiego imperium w Ameryce, [w:] Historia Stanów Zjednoczonych Ameryki, Warszawa 1995, t. 1, s. 36.

82 T. Hobbes, Elementy filozofii, t. 1, Warszawa 1955, s. 128.

83 Cyt. za: N. Chomsky, Requiem dla amerykańskiego snu. 10 zasad koncentracji bogactw $i$ wtadzy, Kraków 2018, s. 10.
} 
pracy Etyka protestancka a duch kapitalizmu. Być może, ta zdolność chrześcijaństwa do wykreowania pozytywnej korelacji między wiarą a kapitalizmem była łabędzim śpiewem tej religii, która została ostatecznie przez niego zdominowana. Lęk przed teologią wyzwolenia, czyli lęk przed opowiedzeniem się po stronie biednych, jest tego najlepszym dowodem. Jest przecież projektowanym na innych lękiem kapitalistycznej mniejszości, która nie ma zamiaru dzielić się zyskami ze społeczną większością. Za to ma pociągający dla tej większości urok, wciąż ponawiając obietnicę raju dla niemal wszystkich. Ironicznie mówiąc, ta mniejszość mniej boi się rewolucji społecznej kiedyś, w przyszłości, niż dzielenia się zyskami dziś w imię jej zapobieżenia. Wątpliwe, czy papieżowi Franciszkowi uda się ten stan rzeczy zmienić.

Mimo zmiany podejścia władzy do kupców i bankierów, podejrzliwość wobec bogactwa, powstającego drogą handlu, czy kredytu, towarzyszyła nam, Europejczykom, aż do XIX w. W monarchiach kapitaliści przegrywali z innymi hierarchiami społecznymi, a tylko wygrana z nimi mogła pokazać wszystkie jego możliwości ${ }^{84}$. Dopiero wskutek rewolucji francuskiej trzeci stan zyskał prawa polityczne, a z czasem dzięki temu narzucił polityce własny punkt widzenia na cele rzeczywistości społeczno-politycznej i na środki ich osiągania.

Obecnie już nie ma wątpliwości, iż efektem zdominowania myślenia społeczeństw i państw przez motywacje kapitalistyczne jest niekontrolowany wzrost nierówności, między państwami. O ile dzisiaj różnica w dochodzie między Szwajcarią a Mozambikiem wynosi $400: 1$, o tyle jeszcze 250 lat temu wynosiła $5: 1^{85}$. Parafrazując Davida Landesa, można powiedzieć, że żyjemy dzisiaj w świecie, dzielącym się na trzy kategorie państw:

- te, w których wydaje się mnóstwo pieniędzy na odchudzanie;

- te, w których ludzie jedzą, aby żyć;

- te, w których ludzie nie wiedzą, skąd wziąć pieniądze na następny posiłek ${ }^{86}$. Nierówności społeczne wewnątrz bogatych krajów również się pogłębiają. Szczególnie odbijają się one na dostępie do służby zdrowia. O ile w Stanach Zjednoczonych między rokiem 1990 a 2000 przeciętna długość życia wzrosła o dwa lata, to takiego wzrostu nie odnotowano wśród najbiedniejszych Amerykanów; wręcz przeciwnie, długość życia biednych Amerykanek uległa nawet skróceniu. Jak podaje Joseph Stiglitz, „Białe nie-Latynoski z wyższym wykształceniem żyją średnio dziesięć lat dłużej niż czarne lub białe kobiety bez dyplomu wyższej uczelni” ${ }^{87}$. Mężczyźni bez wyższego wykształcenia żyją trzy lata krócej od średniej.

\footnotetext{
84 F. Braudel, Dynamika kapitalizmu, Warszawa 2013, s. 87.

85 Zob. D. S. Landes, op. cit., s. 18.

86 Zob. ibidem, s. 17-18.

87 J. E. Stiglitz, Cena nierówności. W jaki sposób dzisiejsze podziały społeczne zagrażaja naszej przyszłości?, Warszawa 2015, s. 11.
} 
Nie ma wątpliwości co do tego, że obecny stan nierówności prowadzi do destabilizacji świata, o czym mówił już Platon. Jak jednak podkreśla Stiglitz, noblista z zakresu ekonomii, „niestety w ostatnich latach ekonomiści nie poświęcili należytej uwagi kwestii nierówności ani innym problemom mogącym być przyczyną niestabilności”88.

\section{Zdeprawowany język istotą współczesnego robienia pieniędzy}

Joseph Stiglitz twierdzi, że prawdziwa innowacyjność współczesnej gospodarki polega na tym, iż ,najbogatsi i najbardziej wpływowi nauczyli się wyciągać pieniądze od pozostałej części społeczeństwa w sposób prawie dla niej niezauważalny" ${ }^{9}$. Ponieważ mamy do czynienia z niemoralnymi praktykami, których celem jest wyłącznie bogacenie się, można zgodzić się z Josephem Voglem, że obecnie „dawna chrematystyka zyskuje nową, uprzywilejowaną przestrzeń dyskursywną"90. Opisowi tego zjawiska poświęcimy się teraz, śledząc zbieżności tych innowacyjnych, a jednak w dużej mierze starych praktyk, $\mathrm{z}$ przewidywaniami Platona.

Wszyscy chyba zgodzimy się z twierdzeniem, że dominacja fałszywych słów, która, jak przewidywał Platon, nastąpi, o ile ludzie pragnący zysku przejmą władzę polityczną, na początku XXI w. stała się nie przypadkowym faktem, lecz normą. Nie doprowadziły do niej naturalne, nieświadome, niekontrolowane i nieuchronne procesy społeczne, jak chcą nas przekonać zwolennicy liberalizmu i neoliberalizmu, ale pozbawione etyczności myślenie określonych grup ludzi na temat maksymalizacji zysku. Zaczęło się od zmiany teorii produkcji i handlu, która, zdaniem Naomi Klein, miała „swoje źródło w niewinnej na pozór idei, wymyślonej przez teoretyków zarządzania w połowie lat 80 ., wedle której żeby odnieść sukces, firma musi stworzyć markę, rozumianą jako przeciwstawienie produktu" ${ }^{91}$. To jest ta innowacyjność w mnożeniu zysków, o której mówi Stiglitz. Przedsiębiorstwa, które ją zastosowały, nazwano przedsiębiorstwami nowego typu, ponieważ w odróżnieniu od klasycznych przedsiębiorstw produkujących, ,sam proces produkcji - zarządzanie fabrykami i związaną z tym odpowiedzialność za dziesiątki tysięcy pełnoetatowych pracowników - zaczęły postrzegać raczej jako kulę u nogi niż pewną drogę do sukcesu"92. W efekcie pod koniec XX w. „międzynarodowe korporacje, kontrolujące ponad 33\% świa-

\footnotetext{
88 Ibidem, s. 63.

89 Ibidem, s. 107

90 J. Vogel, op. cit., s. 123.

91 N. Klein, No Logo, Izabelin 2004, s. 21.

92 Ibidem, s. 22.
} 
towych środków produkcji, odpowiadały bezpośrednio tylko za 5\% wszystkich miejsc pracy"93.

Doprowadziwszy do szeregu korzystnych dla siebie zmian w prawodawstwie, polegających na liberalizacji handlu i reformy prawa pracy94, przedsiębiorstwa typu Nike, Reebok, czy Microsoft ogłosiły, że „produkowanie towarów stanowi jedynie margines ich działalności, że są w stanie przerzucić wytwarzanie swoich produktów na kontrahentów, często z innych kontynentów, że najważniejszym produktem tych firm nie jest określony towar, lecz wizerunek marki”. Dzięki tej zasadniczej zmianie $\mathrm{w}$ podejściu do produkcji przedsiębiorstwa te weszły „na drogę wyścigu do bezcielesności, gdzie wygrywa ten, kto ma najmniejszy stan posiadania, najkrótszą listę płac i kto zdoła wytworzyć najpotężniejszy wizerunek rynkowy, rozumiany jako przeciwstawienie produktu"95. Jak pamiętamy, Platon przewidywał, że wzbogaceni rzemieślnicy (czytaj, producenci) przestaną wykonywać swoje zajęcia. Nie przewidział jednak, że zechcą nadal pomnażać swoje zyski, nieprodukując. To jedna z tych nielicznych rzeczy, o których nawet filozofom się nie śniło, a które mimo to stały się faktem.

Budowanie marki, czyli $\mathrm{z}$ angielska mówiąc branding, o którym tu mowa, jest czymś innym, niż reklama, aczkolwiek do oceny obu można zastosować słowa George'a Orwella, że reklama to bełtanie kijem w wiadrze z pomyjami ${ }^{96}$. Nawiasem mówiąc, mimo że pod tym stwierdzeniem mogłaby się podpisać większość klientów, to „ostatni skuteczny atak na reklamę jako taką - a nie tylko niezgoda na jej treść czy stosowane przez nią techniki - miał miejsce w czasie Wielkiego Kryzysu. W latach 30. już sama idea szczęśliwego, stabilnego społeczeństwa konsumpcyjnego, odmalowywana w reklamach wywoływała oburzenie milionów Amerykanów, dla których zabrakło miejsca w tym śnie o dobrobycie. Powstał ruch przeciwników reklamy, którzy atakowali ją nie za wadliwą metaforykę, lecz jako wszechobecny symbol wadliwego systemu ekonomicznego. To nie reklamowe obrazki doprowadzały ludzi do szewskiej pasji, lecz okrucieństwo jawnie fałszywej obietnicy, którą reprezentowały - kłamstwo Amerykańskiego Snu, wedle którego radośnie konsumpcyjny styl życia nadal był dostępny dla wszystkich" "97. Przyczyna tego ataku była do przewidzenia, bo już Platon mówił, że destrukcyjne jest doprowadzanie do bezpośredniego zderzenia szczęścia i zadowolenia jednych z nieszczęściem innych, a to właśnie miało miejsce w la-

\footnotetext{
93 Ibidem, s. 279.

94 Administracja Reagana mówiła o ,zmianie instytucji i praktyk pracowniczych”, zezwalając na niszczenie ruchu związkowego i obniżanie płac pracowników. Świadczy to o tym, jak bardzo kontrola nad językiem i jego degradacja, zasłaniająca a nie odsłaniająca istotę zjawisk, odgrywa w dzisiejszej ekonomice i polityce kluczową rolę. Zob. N. Chomsky, Zysk ponad ludzi..., s. 90.

95 N. Klein, op. cit., s. 22.

96 Zob. ibidem, s. 321.

97 Ibidem, s. 322.
} 
tach 30., kiedy w Stanach Zjednoczonych niezależni filmowcy kręcili zdjęcia obszarpanych ludzi, stojących w kolejkach po chleb pod olbrzymimi bilbordami reklamującymi mniej lub bardziej luksusowe dobra.

Wróćmy jednak do rozróżnienia reklamy i brandingu. Reklama i branding powstały w tym samym mniej więcej czasie, czyli w drugiej połowie XIX w. Reklama była jednak bardziej rozpowszechniona, popularyzowała bowiem nowe produkty, których wówczas nie brakowało. Branding, czyli tworzenie marki, był natomiast „efektem zalania rynku przez wytwarzane towary, które prawie niczym się od siebie nie różniły" 98 , jak np. płatki owsiane, ryż, buty i temu podobne. Rzeczony ryż, czy buty, nie mogły być tak samo atrakcyjne, jak nowo powstała żarówka, czy radio. Siłą rzeczy, żeby sprzedać swój ryż korzystniej niż inni sprzedawcy, należało wypromować markę, np. Uncle Bens, co też nastąpiło. Potem na branding postawili niemal wszyscy. Istotę zmiany pierwotnej zależności między reklamą a brandingiem trafnie uchwyciła Naomi Klein, pisząc: „,pomyślcie o marce jako podstawowym znaczeniu (treści) nowoczesnej korporacji, o reklamie zaś - jako o środku propagowania tego znaczenia"99.

Pytanie, dlaczego reklama i branding są złe, jest retoryczne. Reklama i branding są złe, ponieważ ludzie się nimi zajmujący z definicji, jak starożytni retorzy i poeci, nie apelują do rozumności swoich klientów, lecz używają słów i obrazów do tego, co w języku potocznym nazywa się „graniem na uczuciach”. „Granie na uczuciach" jest oceniane negatywnie, ponieważ czyni człowieka bezbronnym wobec tego, kto to robi. Za wzbudzanie uczuć i jednoczesne usypianie rozumu (pierwsze wszak zawsze jest związane z drugim) Platon chciał wyrzucić poetów z państwa. Mądrość naszych przodków, tworzących polski język, jest po stronie Platona, przypisując „graniu na uczuciach” manipulatorski charakter.

Naomi Klein, która badaniu powstania i skutków reklamy i brandingu poświęciła swą pracę No Logo, a ściślej, No Space, No Choice, No Jobs, tak pisze o początkach procesu „uduchowiania” (!) tej działalności: „na początku lat 20. legendarny spec od reklamy Bruce Barton uczynił z General Motors metaforę amerykańskiej rodziny, «coś osobistego, ciepłego i ludzkiego», a GE przestało być nazwą pozbawionego twarzy General Electric Company, by stać się, wedle słów Bartona, «inicjałami przyjaciela»" "100. Warto napomknąć, że Barton był synem kaznodziei i chętnie powoływał się na swoje religijne wychowanie. Czyżby z tamtej działalności czerpał natchnienie? Tak, czy inaczej, należało się spodziewać, że granie na uczuciach raz rozpoczęte będzie zaledwie początkiem drogi, prowadzącej do utworzenia kultury, czy wręcz religii marki. W tym celu samemu aktowi odwoływania się do uczuć klientów nadano profesjonalny charakter. Do

\footnotetext{
98 Ibidem, s. 23.

99 Ibidem, s. 23.

100 Ibidem, s. 24.
} 
tej pracy dali się zaprząc humaniści, marzący o byciu użytecznymi. Mogli, jako humaniści, być użytecznymi, broniąc ludzi przed manipulowaniem. Woleli jednak wybrać służenie manipulatorom.

Pod koniec lat 40. wraz z rozwojem brandingu ,agencje, poszukujące prawdziwego znaczenia marki (...) stopniowo przestały zajmować się pojedynczymi artykułami i ich atrybutami, poświęcając się zamiast tego badaniu znaczenia marek dla kultury i życia jednostek, ujmowanego z punktu widzenia psychologii i antropologii. Badania owe uważano za rzecz pierwszej wagi, zgodnie z teorią, że korporacje mogą sobie wytwarzać produkty, ale tym, za co płacą konsumenci, jest marka"101. Powstaje pytanie, dlaczego ludzie płacą za markę, a nie po prostu za produkt? Odpowiedź jest dość prosta i świadczy o tym, że rządzą nami te same potrzeby, co naszymi przodkami. Wykorzystano tu, od zawsze towarzyszącą cywilizacjom, chęć klas podporządkowanych do podszywania się przez ubiór i inne akcesoria pod klasy dominujące. W starożytności czy średniowieczu, jak pamiętamy, reglamentowano materiały, wzory i kolory ubiorów, żeby z braku dowodów osobistych z daleka nawet na pierwszy rzut oka dało się chociażby w przybliżeniu ustalić przynależność klasową jednostek. Każdej przecież należał się inny sposób jej traktowania. Teraz zaczęto czynić coś dokładnie odwrotnego, czyli kupczyć artefaktami pozycji społecznej, świadomie sprzedając iluzję współprzynależności do tzw. lepszego towarzystwa. Jak ironicznie podsumowuje tę praktykę Naomi Klein, „Na tej fali markowej manii wypłynął nowy gatunek biznesmena, ktoś, kto poinformuje cię z dumą, że Marka $\mathrm{X}$ to nie produkt, lecz sposób na życie, światopogląd, zespół wartości, wizja, idea. Brzmi to naprawdę wspaniale - o wiele lepiej, niż gdyby powiedzieć, że Marka X to śrubokręty, hamburgery albo para dżinsów, czy nawet szczególnie udanych butów do biegania" 102 .

Odcieleśnianie firm, polegające na odłączenie procesu produkcji od marki, nabrało nowego tempa po pojawieniu się sprzedaży internetowej. ,Internet umożliwia markom funkcjonowanie w najczystszej formie: wolne od balastu sklepów i procesu produkcyjnego, mogą swobodnie bujać w wirtualnych obłokach, odgrywając bardziej rolę zbiorowych halucynacji niż szafarzy towarów i usług" ${ }^{103}$.

Proces zdobywania przez branding przewagi nad produkcją zakończył się w latach 80 . kiedy to ,narodziła się prawdziwa mania rynkowej wartości marki, która znalazła swój ostateczny wyraz w zapłaceniu w 1988 roku przez Philipa Morrisa 12,6 miliarda dolarów za korporację Kraft - sześć razy tyle, ile firma była warta na papierze. Różnica najwidoczniej stanowiła cenę za słowo «Kraft». (...) wydarzenie to uradowało świat reklamy, który mógł teraz ogłosić,

\footnotetext{
101 Ibidem, s. 25.

102 Ibidem, s. 41.

103 Ibidem, s. 40.
} 
że wydatki na kampanie reklamowe nie są li tylko elementem strategii marketingowej, lecz inwestycją w zimną, twardą wartość rynkową firmy"104.

Pogoń marek za zyskiem spowodowała niechlubny mariaż korporacji i życia akademickiego. Naukowość dobrze się sprzedaje, a właściwie nie naukowość, a opinia o naukowości, o czym pisał już Platon. Proces ten rodzi potworki, albowiem „Firmowane przez uczelnię badania przykrawa się na miarę ufundowanych przez korporacje katedr, szafujących imponującymi tytułami (na przykład «wybitny profesor hotelarstwa i restauratorstwa Taco Bell» na Uniwersytecie Stanowym Waszyngton, «katedra technologii systemów informacyjnych Yahoo!» na Uniwersytecie Stanforda czy «katedra badań naukowych Lego» w Massachusetts Institute of Technology)" ${ }^{105}$. Uniwersytet Stanforda, czy MIT to przecież wiodące uczelnie wyższe USA. Jeśli one nie oparły się zarabianiu w ten sposób, czego można się spodziewać po jednostkach o dużo mniejszej renomie i gorszej sytuacji finansowej?

Demoralizacja systemu z udziałem i wsparciem ze strony naukowców odbywa się też w inny sposób. Wprzęgnięci w pogoń za użytecznością, przyjęli oni na siebie rolę starogreckich retorów, zdolnych uzasadnić dowolną tezę „,naukową", o ile im się za to odpowiednio zapłaci. Zamiast upowszechniać wiedzę, jak greccy retorzy upowszechniali wiarę w pewne przekonania, służące korporacjom. „Na przykład firmy tytoniowe dodawały do swoich wyrobów substancje uzależniające, a kiedy próbowały przekonać Amerykanów, że nie ma żadnego «naukowego dowodu» na szkodliwość oferowanych przez nie produktów, prezentowały masę danych na poparcie swojego stanowiska. Podobnie spółka paliwowa ExxonMobile wydawała pieniądze, by przekonać Amerykanów, że nie ma wiarygodnych dowodów potwierdzających tezę o globalnym ociepleniu, mimo że National Academy of Sciences (NAS) i inne państwowe instytucje naukowe są zgodne co do tego, że zjawisko to rzeczywiście ma miejsce"106. Podobnie, jak na greckiej agorze, współczesny, wykształcony skądinąd, tłum nie słucha jednak naukowców, dysponujących wiedzą, lecz umiejących ich uwieść słowami speców od reklamy i marketingu.

Manipulacja okazała się niezbędna również w bankowości, która nie pożycza już zwyczajnie pieniędzy na procent, a sprzedaje produkty. Potrzebuje więc reklamy, wspierającej pogoń banków za rentą, czyli nienależnym zyskiem. Stiglitz pisze o tym następująco, używając przy tym platońskich i średniowiecznych wręcz epitetów: „Najbezczelniejsza metoda pogoni za rentą - doprowadzona do perfekcji w ostatnich latach - polega na opanowaniu przez speców z sektora finansowego umiejętności wykorzystywania ubogich i niezorientowanych, na

\footnotetext{
104 Ibidem, s. 25-26.

105 Ibidem, s. 119.

106 J. E. Stiglitz, op. cit., s. 48-49.
} 
których zbijali ogromne fortuny, naciągając ich na skrajnie niekorzystne pożyczki i karty kredytowe przyznawane na nieuczciwych warunkach"107. Bezczelność, spece, wykorzystywanie, naciąganie, nieuczciwość - wszystkie te epitety nie brzmią jak pojęcia z podręczników do ekonomii, ale jak wprost zaczerpnięte z języka potocznego, z całym ich ładunkiem ocennym. Używa ich ekonomista z Nagrodą Nobla, a dla każdego obywatela mieć po swojej stronie takiego sojusznika jak noblista Stiglitz jest rzeczą nie do przecenienia, choćby na razie miało oznaczać zaledwie posiadanie wsparcia w krytyce ustroju, bez perspektyw jego zmiany w jakiejś bliskiej przyszłości.

Ponieważ banki to pracujący w nich ludzi, w związku z tym urabianie klientów musiało być najpierw wsparte urabianiem tych, co z nimi bezpośrednio pracowali. Stiglitz mówi o tym, że ci, „którzy decydowali (...) o angażowaniu kierowanych przez siebie instytucji w nieuczciwe i nieetyczne praktyki, (...) także tworzyli w nich kulturę takim praktykom sprzyjającą" ${ }^{108}$. Częścią tej kultury było budowanie poczucia własnej sprawczości i dumy z tejże wśród pracowników korporacji. W efekcie człowiek ,reklamy przestał uważać się za usługodawcę walczącego o klienta, stając się we własnych oczach, by zacytować krytyka reklamy Randalla Rothberga: królem-filozofem kultury reklamy"109. Nawiasem mówiąc, uważanie się za króla-filozofa jest bezpośrednim nawiązaniem do platońskiej koncepcji państwa idealnego, ale w przytoczonym przykładzie król-filozof, mistrz manipulacji, jest osobnikiem stanowiącym dokładną odwrotność platońskiego króla-filozofa, który nie myśli o wąsko pojętym interesie własnym, czy jakiejś grupy, a dobrostanie i trwałości całej wspólnoty.

Drugą stroną przekonania o własnej dominacji jest przekonanie o znacząco niższej wartości klienta. Jak pisze Naomi Klein, „David Lubars, jeden z szefów agencji reklamowej Omnicom Group, wyjaśnia podstawową zasadę, którą kieruje się przemysł reklamowy, ze znacznie większą otwartością niż większość jego kolegów po fachu. Konsumenci, powiada, «są jak karaluchy - spryskujesz ich, spryskujesz, a oni natychmiast się uodparniają»" ${ }^{110}$. Nic dziwnego, że ten pełen pogardy język opanował świat polityki, skoro marketing polityczny ma do czynienia z tą samą grupą docelową, co handlowcy. Klienci to przecież wyborcy, których podobnie jak klientów wabi się różnymi hasłami, ale w rzeczywistości się ich nie szanuje. Personalnym zwieńczeniem brandingu i polityki jest wybór Donalda Trumpa na Prezydenta Stanów Zjednoczonych. Trump słynie bowiem przede wszystkim ze sprzedaży marki Trump i nie jest właścicielem większości hoteli, czy pól golfowych, występujących pod tą marką.

\footnotetext{
107 Ibidem, s. 114.

108 Ibidem, s. 56.

109 N. Klein, op. cit., s. 25.

110 Ibidem, s. 27
} 
Politykę i szeroko rozumiany handel łączy też fakt, że obie korzystają, kiedy jednostka staje się częścią tłumu, o którym Platon mówi, że jego konstytutywną cechą jest niewiedza, a w związku z powyższym kieruje się owczym pędem. Sukcesem kapitalistów jest kontrolowane przekształcenie jednostek w masę dzięki odpowiedniemu użyciu nowych możliwości technicznych. „W tej nowej masie jest się masą jako jednostka. W konsekwencji dzisiejsze (...) społeczeństwa nie orientują się już głównie na cielesne doświadczanie siebie samych, lecz obserwują się tylko poprzez medialne symbole, poprzez dyskursy, mody, programy i preferowane wartości. W tym właśnie ma systemową podstawę indywidualizm masowy naszej epoki” ${ }_{111}$. „Bądź sobą, pij Pepsi”, albo „kiedy jesteś głodny, nie jesteś sobą. Zjedz więc snickersa" - nawołują reklamowe hasła, sugerując, że stawanie się podmiotem, polega na czynieniu tego, co czynią inni, czyli kupowaniu produktu odpowiedniej firmy. Ten chwyt marketingowy jest zarazem bezprzykładnym aktem psychopolitycznym. Wywyższanie się przez kupowanie markowych rzeczy to bowiem ,próba zmierzająca do tego, by ruchliwe, zazdrosne, pędzone ambicjami masy, które nieustannie rywalizują ze sobą o eksponowane pozycje, uchronić przed stoczeniem się w groźne depresje przegranych" 112 .

Podobnym psychopolitycznym aktem jest wykorzystywanie przez rządzących wiedzy psychologicznej, żeby „tak kształtować sposób myślenia ludzi, by różnice w dochodach, które byłyby czymś rażącym, wydawały się możliwe do zaakceptowania" 113

W charakterze podsumowania przytoczymy kilka konstatacji dokonanych przez polskiego ekonomistę Witolda Orłowskiego i cytowanego po wielokroć Josepha Stiglitza. Wszystkie one mają platoński wydźwięk.

Witold M. Orłowski w artykule Pogoń za zyskiem, analizując przyczyny i lekcje, płynące z kryzysu na rynku pieniężnym z 2008 r. praktycznie bezustannie odwołuje się do kategorii psychologicznych, opisujących zachowania się ludzi i instytucji, czyli też ludzi. Ogólny wniosek jego artykułu można by streścić w jednym porzekadle: historia uczy, że niczego nie uczy. Nie uczy zaś dlatego, że jak twierdził już Platon, kto ma wrodzoną cechę pożądliwości, tego nawet własny długofalowy interes nie powstrzyma przed zrobieniem interesu tu i teraz kosztem przyszłości. Autor artykułu, o którym mowa, nie powołuje się na Platona, ale proszę zwrócić uwagę o jakich trzech rzeczach każe nam pamiętać:

„1. Choć obecny kryzys doprowadził do zmian na rynku finansowym, to podstawowe, fundamentalne zagrożenia nie zniknęły. Banki nadal są gotowe gonić za szybkim zyskiem i unikać nadzoru, a determinacja, z jaką starały się spłacić rządom ratunkowe pożyczki, po to by jak najszybciej pozbyć się przed-

\footnotetext{
111 P. Sloterdijk, Pogarda mas, Warszawa 2012, s. 23,

112 Ibidem, s. 148.

113 J. E. Stiglitz, op. cit., s. 104.
} 
stawicieli państwa ze swych rad nadzorczych, daje do myślenia. (...) Państwowy nadzór nadal nie będzie w stanie kontrolować najbardziej ryzykownych operacji, a pomysłowość bankowców w tworzeniu nowych instrumentów finansowych zawsze będzie wyprzedzać kontrolę.

2. Nigdy nie znikną czynniki umożliwiające powstawanie fal nadmiernego optymizmu. Tutaj w grę wchodzą fundamentalne wady ludzkiego umysłu, jak np. lekceważenie ryzyka czy uleganie owczemu pędowi.

3. Nawet najbardziej bolesne lekcje nie stają się trwałym ostrzeżeniem" ${ }^{114}$.

W punkcie pierwszym mamy pogoń za zyskiem i pomysłowość (,starożytną chytrość”) w wymyślaniu sposobów, jak zysk osiągnąć, czyli niczego nieuczące się emocje po stronie robiących pieniądze, traktujące rozum instrumentalnie. W punkcie drugim znowu niczego nieuczące się emocje, tym razem po stronie klientów. W punkcie trzecim, kolejne skonstatowanie tego, że ci, o których mowa w punkcie jeden i dwa, choćby nie wiem, co im się przytrafiło, i tak nie mogą się oduczyć pogoni za zyskiem i ulegania owczemu pędowi. Oba te potoczne wyrażenia mówią o tak silnych namiętnościach, władających ludźmi, że z pewnością można te zachowania nazwać irracjonalnymi. I tylko jedną wadę można przypisać opisowi dokonanemu przez Orłowskiego, a mianowicie, że niedostatecznie uwypuklił fakt, że owczy pęd nie jest tylko samoistną cechą większości ludzi, ale może i jest metodycznie wywoływany przez kapitalistów.

Ogólna ocena kapitalistów, dokonana przez J. Stiglitza brzmi następująco: „Ludzie biznesu oczywiście (Platon by mu pogratulował tego „oczywiście” - dop. E. M.) nie skupiają się na tym, by zwiększyć szeroko rozumiany dobrobyt społeczny czy choćby na tym, by na rynku istniała większa konkurencja: chcą po prostu by rynki działały dla nich, by ich interesy były bardziej zyskowne"115. I dalej, „trudno zakładać, że rynki są zasadniczo efektywne. A to znaczy, że państwo ma do odegrania potencjalnie niezwykle istotną rolę polegającą na korygowaniu ich ułomności" 116.

Krytykując zaś sugestię o nieuchronności i bezalternatywności obecnego stanu rzeczy w ekonomii, która to sugestia stanowi istotę dyskursu neoliberalnego, Stiglitz pisze: „Często słyszymy, że tak musi być, że globalizacja nie daje nam możliwości wyboru. Ten fatalizm będący na rękę beneficjentom obecnego systemu zaciemnia prawdziwy obraz rzeczywistości: mianowicie to, że w obecne tarapaty popadliśmy $\mathbf{z}$ własnego wyboru. Rządy naszych państw wybrały gospodarczy model globalizacji, który tak naprawdę wiązał ręce naszym demokracjom. Najbogatszy 1 procent zawsze niepokoił się, że demokracje, na przykład pod naciskiem populistycznego lidera, będą chciały ustanowić «nadmiernie» pro-

114 W. M. Orłowski, Pogoń za zyskiem, „Polityka” 2018, nr 37, s. 41.

115 J. E. Stiglitz, op. cit., s. 111.

116 Ibidem, s. 110. 
gresywne opodatkowanie. Teraz wmawia się obywatelom, że na takie rozwiązanie nie mogą sobie pozwolić - oczywiście, o ile chcą uczestniczyć w globalizacji”"117. Pojęcia „wybór” (po stronie rządzących) i „wmawianie”, jako kwintesencja zdegenerowanej, manipulatorskiej mowy, skierowanej pod adresem rządzonych, są klamrą spinającą ocenę obecnej sytuacji społeczeństwa z tą, która została dokonana swego czasu przez Platona.

Konkludując, Stiglitz pisze: „Kapitalizm nie tylko nie przynosi tego, co obiecał, ale też powoduje skutki, przed jakimi nie ostrzegał: pogłębia nierówności, zanieczyszcza środowisko, zwiększa bezrobocie i - co najgorsze - prowadzi do upadku wartości na taką skalę, że wszystko staje się dopuszczalne i nikt za nic nie odpowiada" 118 .

\section{Alternatywna ekonomia - powrót do Platona?}

Dyskusja o kapitalizmie ma jednak nie tylko moralny, lecz także czysto ekonomiczny wymiar. Kapitalizm jest pewną teorią i chodzi o cenę wcielania w życie tej teorii. Była o tym mowa na początku tego artykułu, kiedy to cytowaliśmy Fukuyamę. Można powiedzieć, że „gospodarki narodowe nadal stoją wobec pytania, czy i jak długo będą mogły sobie pozwolić na finansowanie swoich idei kapitalistycznego funkcjonowania i kapitalistycznych struktur" 119 . Sporo wiadomo o tym, ile zapłacił rząd USA za ratowanie upadających banków. Unia Europejska też na tym polu ma swoje ,,sukcesy”: „,w latach 2007-2009 ratowanie upadających prywatnych banków inwestycyjnych kosztowało państwa Unii ok. 4 bln euro - więcej niż słynny i trwający równolegle bailout w Stanach Zjednoczonych. Ceną wyciągania z kłopotów finansjery obarczono budżety państw, co doprowadziło do gwałtownego wzrostu długu publicznego we wszystkich krajach Unii ${ }^{120}$. Nawet słynne umorzenie połowy greckiego długu w 2011 r. polegało na tym, że EBC wykupił od prywatnych inwestorów papiery rządu w Atenach po cenach wyższych niż te, które mogliby oni dostać sprzedając je na rynku. Trudno o lepszą zachętę do dalszych spekulacji" ${ }^{121}$. Cena, o której tu mowa, to jedno, ale najważniejsze, że jak wskazuje francuski socjolog Alain Touraine, „w żadnym kraju nie ma dziś siły politycznej zdolnej (...) narzucić określone reguły działalności kapitalizmu finansowego"122. Wydaje się, że również oddolne inicjatywy

\footnotetext{
117 Ibidem, s. 260.

118 Ibidem, s. 49.

119 J. Vogel, op. cit., s. 168.

120 P. Wielgosz, Koniec Europy jakq znamy, Warszawa 2013, s. 10.

121 Ibidem, s. 11.

122 A. Touraine, Po kryzysie, Warszawa 2013, s. 11.
} 
skazane są na porażkę ponieważ ,świat zdominowanych jest tak bardzo różnorodny i wewnętrznie podzielony, że w żaden sposób nie może się narodzić nowy aktor historyczny, tzn. wola zbiorowego działania, pragnąca wpływać na główne orientacje życia społecznego"123, chyba że będzie nim faszyzm. W związku z powyższym, ciśnie się następujące pytanie: może zamiast zastanawiać się nad ceną realizacji dotychczasowej teorii, warto pokusić się o stworzenie nowej, zdolnej do społecznej mobilizacji jednostek?

Stiglitz poszukuje teorii alternatywnej wobec neoliberalizmu, w której na poziomie metodologicznym upatruję zasadniczych podobieństw z Platonem. Wskazuje on, że w jego teorii ,niedoskonałości rynku, a zwłaszcza niedoskonałości informacji i czynnik «irracjonalności», będą odgrywać zasadniczą rolę" ${ }^{124}$. W określaniu przez Platona jednostek, działających na rynkach, jako pożądliwych, kryje się to samo przekonanie o ich niedoskonałości i irracjonalności, co u Stiglitza. Dobra teoria powinna uwzględniać rzeczywiste, a nie wymyślone cechy osób, działających w sferze ekonomicznej, i obaj autorzy to czynią. Czy jednak w budowaniu alternatyw można posunąć się dalej, poza ogólne metodologiczne wskazówki? Odpowiedź na to pytanie jest materiałem na zupełnie inny artykuł.

\section{Why is it still worth to read Plato, or differently about money}

\section{Summary}

The aim of the article is to show how thinking and acting are closely interrelated, and because of that, methodological disabilities in practicing any science, and social sciences and humanities in particular, have enormous practical effects. According to this thesis, both the science which wants to be directly related to the practice understood as multiplying the profit, as well as the one that programmatically separates from such an activity, have certain practical consequences. The main question that is ignored by both ways of practicing science concerns ethical effects of all human activities, especially scientific and economic ones. It causes excessive influence of emotional people -mainly those who are greedy and prone to aggression - on the functioning of societies. Science cannot change them, it can only be used by them. The inability to change their negative impact on societies was already ascertained by Plato. The only solution to the situation is to return to the historical principle of limiting the political influence of people who are guided by passions and to create an alternative economy that takes into account the knowledge of human nature, based on reasonableness and not greed.

Key words: science, knowledge about a man, economics, ethics, society

123 Ibidem, s. 31.

124 J. E. Stiglitz, op. cit., s. 59. 


\section{Bibliografia}

Arendt H., Kondycja ludzka, Warszawa 2000.

Attali J., Żydzi, pieniqudze, świat, Warszawa 2003.

Bourdieu P., Zaproszenie do socjologii refleksyjnej, Warszawa 2001.

Braudel F., Dynamika kapitalizmu, Warszawa 2013.

Chomsky, Polityka. Anarchizm. Lingwistyka, Poznań 2007.

Chomsky N., Requiem dla amerykańskiego snu. 10 zasad koncentracji bogactw $i$ władzy, Kraków 2018.

Chomsky N., Zysk ponad ludzi. Neoliberalizm a ład globalny, Wrocław 2000.

Człowiek Rzymu, Warszawa 2000.

Człowiek średniowiecza, red. J. Le Goff, Warszawa 2000.

Friedman G., Następna dekada. Gdzie byliśmy i dokąd zmierzamy, Kraków 2012.

Fukuyama F., Koniec historii, Poznań 1996.

Gawroński A., Dlaczego Platon wykluczył poetów z Państwa? U źródeł wspótczesnych badań nad językiem, Warszawa 1984.

Grecja klasyczna 500-323 p.n.e., Warszawa 2002.

Hobbes T., Elementy filozofii, Warszawa 1955.

Israel J. I., Żydzi europejscy w dobie merkantylizmu (1550-1750), Warszawa 2009.

Klein N., No Logo, Izabelin 2004.

Landes D. S., Bogactwo i nędza. Dlaczego jedni sq tak bogaci, a inni tak ubodzy, Warszawa 2005.

MacIntyre A., Czyja sprawiedliwość? Jaka racjonalność?, Warszawa 2007.

Orłowski W. M., Pogoń za zyskiem, „Polityka” 2018, nr 37.

Platon, Gorgias, Warszawa 1991.

Platon, Państwo, Kęty 1997.

Platon, Prawa, Kęty 1997.

Platon, Timajos, Warszawa 1986.

Popularna Encyklopedia Powszechna, Kraków 2003.

Rozbicki M. J., U źródet brytyjskiego imperium w Ameryce, [w:] Historia Stanów Zjednoczonych Ameryki, t. 1, Warszawa 1995.

Sloterdijk P., Pogarda mas, Warszawa 2012.

Smith A., Badania nad natura i przyczynami bogactwa narodów, Warszawa 1954.

Stiglitz J. E., Cena nierówności. W jaki sposób dzisiejsze podziały społeczne zagrażaja naszej przyszłości?, Warszawa 2015.

Touraine A., Po kryzysie, Warszawa 2013.

Vogel J., Widmo kapitału, Warszawa 2015.

Voegelin E., Nowa nauka polityki, Warszawa 1992. 
Wallerstein I., Europejski uniwersalizm. Retoryka władzy, Warszawa 2007.

Wallerstein I., Koniec świata jaki znamy, Warszawa 2004.

Wallerstein I., Utopistyka. Alternatywy historyczne dla XXI wieku, Poznań 2008.

Wielgosz P., Koniec Europy jakq znamy, Warszawa 2013. 